\title{
A PAISAGEM EM CRIÚVA E VILA SECA, CAXIAS DO SUL, BRASIL: UMA NARRATIVA ETNOGRÁFICA
}

\author{
Claudia Ribeiro ${ }^{1}$ \\ José Carlos Gomes dos Anjos ${ }^{2}$ \\ Guilherme Francisco Waterloo Radomsky ${ }^{3}$
}

\section{Introdução}

2011. Na abertura de uma palestra de dois agrônomos da Prefeitura Municipal de Caxias do Sul, uma imagem conforma um caminho de pesquisa. Nesse pronunciamento, eles explicam sobre o desenrolar do "Projeto de Preservação das Águas de Criúva e Vila Seca": dois distritos rurais da cidade, seu local de trabalho, situados nos Campos de Cima da Serra (Facchin et al., 2007). A montagem fotográfica que introduz esta apresentação é a primeira impressão da paisagem de um lugar, que logo a seguir constituirá, a um só tempo, tema de interesse e campo empírico de estudos na pósgraduação em Desenvolvimento Rural da Universidade Federal do Rio Grande do Sul. ${ }^{4}$

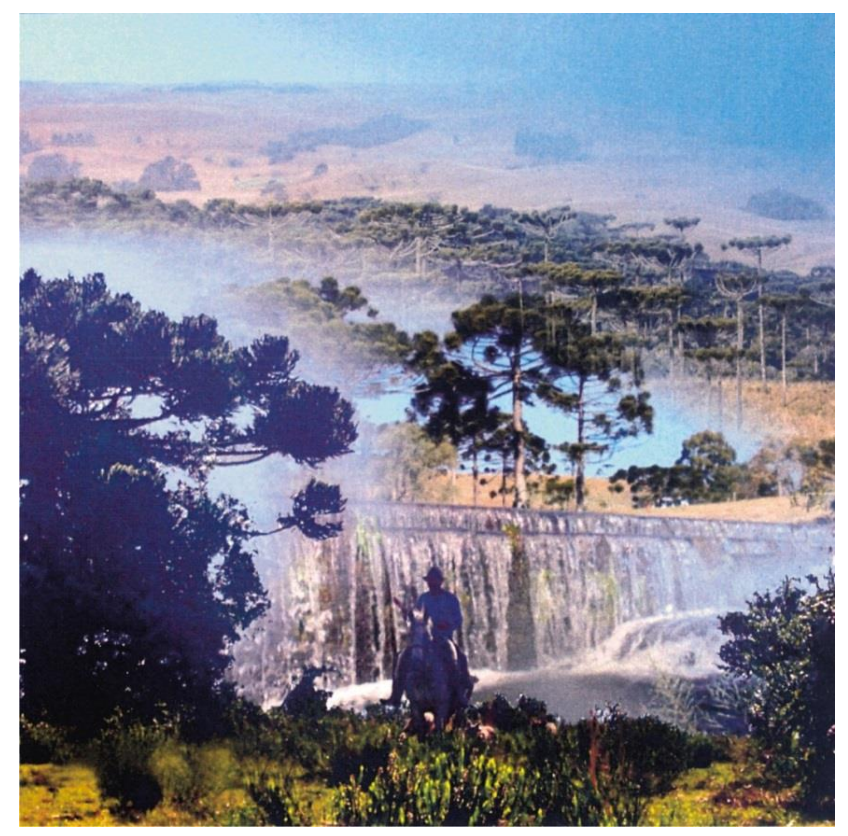

Figura 1: Paisagem de Vila Seca e Criúva. Fonte: Facchin et al. (2007).

\footnotetext{
${ }^{1}$ Universidade Federal do Rio Grande do Sul, Brasil.

${ }^{2}$ Universidade Federal do Rio Grande do Sul, Brasil.

${ }^{3}$ Universidade Federal do Rio Grande do Sul, Brasil.

${ }^{4}$ Dissertação de mestrado conduzida com o suporte de bolsa de pesquisa da CAPES - Coordenação de Aperfeiçoamento, com resultado integralmente disposto em Ribeiro (2014).
} 
Pronta e intuitivamente, entende-se essa deliberada composição como uma tentativa de síntese, um primeiro apanhado dessa paisagem. Mas, mais do que isso, nota-se a vontade subjacente de enfatizar nessa paisagem, que se sabe ser alvo de ação de proteção ambiental, a particularidade dos seus humanos habitantes. A silhueta da figura montada e seu cavalo, recortada contra a abundante cortina de água e circundada por um mosaico de campo e floresta, sinaliza de alguma forma os dramas da ruralidade local.

Caxias do Sul, centro da conurbação urbana do nordeste, segundo Pereira e Lemos (2003), está no limite superior de classificação dos municípios brasileiros de porte médio: com quase meio milhão de habitantes, o município é relevante polo de atividades comerciais e industriais.

Seu aglomerado urbano principal dista dos maiores cursos d'água da região, os rios Caí e Taquari-Antas. Por essa razão é que a já praticamente segunda metrópole gaúcha vai buscar na rede de pequenos arroios da região dos Campos de Cima da Serra a água para seu abastecimento urbano, industrial e doméstico. Dois reservatórios em Vila Seca, dos arroios Faxinal e Marrecas, são ditos como hoje podendo abastecer até $70 \%$ de suas necessidades de água potável. E é na esteira desta lógica de paulatino acesso aos "recursos naturais" mais próximos, que o seu planejamento municipal - de origem urbana - projeta que a expansão futura dessa demanda será atendida por barramentos nos arroios Mulada e Sepultura, no distrito vizinho de Criúva. Essa atitude, expressa na definição das Zonas de Produção de Água, sobreposta às polêmicas e movediças deliberações em torno do manejo com fogo associado à pecuária em campos autóctones da região dos Campos de Cima da Serra, são exemplos pungentes de deliberações urbanas que acabam trazendo consigo uma série de restrições à vida de predominantes atividades agrícolas dos habitantes do lugar: 3.916 pessoas, que em 2010 tiveram seu domicílio registrado nos $614 \mathrm{~km}^{2}$ desses dois distritos, compreendendo $38 \%$ da área total do município (IBGE 2010a; 2010b; Sartori, 2005).

Os detalhes da discussão teórica e metodológica e o evidenciar sucinto de resultados da pesquisa exploratória que embasa a discussão aqui introduzida são encontrados em Ribeiro, Dal Forno e Miguel (2015). Neste momento se registra sua procura maior: a realidade trajetiva ${ }^{5}$ da paisagem - ocorrendo no espaço (o meio) e no tempo (a história), em sua contínua interação de aspectos subjetivos e objetivos. Esse

\footnotetext{
${ }^{5}$ Referente à sua trajeção: movimento de contínua interação entre os mundos objetivos e subjetivos, que compõe a realidade dos nossos meios, cujo conjunto constitui a ecúmena (Berque, 2011: 188; 193 e 194).
} 
referido estudo da paisagem conduz-se através de abordagem etnográfica, guiada pelas possibilidades de compreensão da ruralidade aportadas por categorias conhecidas pelo estudo dos seus sistemas agrários. Objetivamente, aí verifica-se que as atividades agrícolas dos agricultores familiares apresentam estreita associação ao mosaico do campo e de floresta característico dessa paisagem: a longeva macroapresentação do Bioma Mata Atlântica na região. O estudo cartográfico, quantificando as porções de mata e campo nativos em 1871, 1980 e 2011 (compreendendo os sistemas agrários sesmeiro, colonial e contemporâneo), consegue demonstrar esse fato. Uma vez cessando o processo de predação da Floresta Ombrófila Mista (fundado no urbano), a paisagem do lugar se refaz, em relação com a continuidade da pecuária semiextensiva e dos policultivos coloniais.

A partir desse ponto, este artigo desvela o coração narrativo da trajeção dessa paisagem. Isso é feito pelo relato reflexivo do trabalho etnográfico em contexto multidisciplinar que a trouxe à tona - o acompanhamento do ciclo de festejos do Divino Espírito Santo que anualmente ocorre nos dois distritos, no caso reportado, realizado no período de dezembro de 2012 a junho de 2013. A escolha desse evento justificou-se pela interpenetração dessas atividades com a ruralidade do lugar. Uma vez que essas atividades, ao mesmo tempo em que levam a benção do Divino aos moradores da região de uma maneira geral, especificamente buscam os donativos para a festa junto aos moradores rurais, em ações que remetem ao que os estudos de José de Souza Martins $(1975: 108,109)$ identificam de maneira particular na Festa do Divino: "as regularidades da natureza e as regularidades da religião combinam-se em função do trabalho rural, da atividade humana sobre a natureza". Finalmente, realiza-se breve discussão em relação aos caminhos de aprofundamento desse estudo etnográfico, em presente continuidade nessa mesma abrangência empírica. 


\section{Alcançando a narrativa da paisagem de um lugar}

Ao início da pesquisa, em estreita relação com a paisagem, preliminarmente se conhece o desenrolar histórico da relação das populações humanas com a agricultura no lugar. O quadro disposto a seguir demonstra a delimitação temporal dos quatro sistemas agrários que são ali verificados.

\begin{tabular}{|l|l|}
\hline Sistema agrário indígena & 10.000 A.C. até 1760 \\
\hline Sistema agrário sesmeiro & 1760 a 1912 \\
\hline Sistema agrário colonial & 1912 a 1980 \\
\hline Sistema agrário contemporâneo & 1980 ao presente \\
\hline
\end{tabular}

Quadro 1: Sistemas agrários em Vila Seca e Criúva. Fonte: Ribeiro (2014: 126).

Das práticas de caça e coleta e incipiente agricultura dos primeiros habitantes Kaingang, chega-se aos cultivos policoloniais e pecuária semiextensiva dos caxienses de hoje. O gado é introduzido na região em três grandes sesmarias, onde a mão de obra das atividades agrícolas (capitaneadas por açorianos, lagunenses e paulistas) é constituída por escravos de origem africana e homens livres - que, como os rebanhos bovinos, espalham-se pelo Rio Grande do Sul após a destruição das missões jesuíticas. Só depois desses acontecimentos todos é que chegam os colonos europeus, predominantemente italianos na região. Os imigrantes passam a comprar terras devolutas em Vila Seca e Criúva a partir da saturação das colônias a eles de primeiro designadas. Ao final desse período colonial é que os dois distritos, que inicialmente faziam parte de São Francisco de Paula, passam a integrar o município de Caxias do Sul.

Descobre-se que esta ruralidade tece rica trama de atividades culturais: muitas festas religiosas católicas são ali presentemente conduzidas. Além disso, intenso calendário de lazer e esporte tem origem em práticas pregressas de lida no campo, como exemplificam os torneios de laço e as cavalgadas variadas que são intensamente conduzidas no lugar.

A partir dessa primeira exploração e de acordo aos estudos multidisciplinares que se conduzem (da ruralidade e da paisagem), decide-se empregar a abordagem etnográfica para o estudo desse campo empírico. Dessa forma origina-se a realização de 
observação participante e entrevistas em um ciclo de atividades que envolvem a preparação da Festa do Divino Santo em Vila Seca - que mantém contato estreito com as mesmas festividades em Criúva ao longo do tempo. ${ }^{6}$

Não havendo como ater-se simultaneamente a todas as festividades, decidiu-se por acompanhar a de Vila Seca - por ali ter sido feito o trabalho de prospecção da ruralidade, e também pela sua localização geográfica, mais próxima à zona urbana de Caxias do Sul. Dentre as várias atividades comunitárias desenvolvidas na organização desse ciclo festivo (conforme detalhado mais adiante), definiu-se um recorte de inclusão nas atividades do grupo de pessoas que conduz a louvação de Vila Seca. Por isso acompanharam-se as visitas que foram feitas aos campos (que é como é nominada a área rural pelos próprios festeiros), assim como alguns dos seus contatos com o mundo externo à Vila Seca. Melhor explicando, esses contatos englobaram visitas à Criúva e a outras localidades próximas e todas as instâncias oficiais visitadas.

As visitas vão sendo programadas e definidas na medida da disponibilidade dos 42 casais de alferes. Cada um deles acompanha os festeiros na sua localidade, sendo também bastante considerada na programação a oferta de uma refeição nesses dias inteiros de louvação nos campos. Pois as distâncias são longas, e os trabalhos mais intensos são sempre nos finais de semana ou nos feriados: algumas dessas jornadas na zona rural começaram às sete e meia da manhã e acabaram perto da meia-noite.

É importante que se diga que as atividades das festas de Vila Seca e Criúva são praticamente simultâneas. Ocorrem com defasagem de poucos dias, para que os momentos festivos finais não coincidam. Contudo existem convites mútuos, que são cuidadosamente honrados por um grupo de festeiros e outro, há casais de alferes que participam das duas festas e pessoas que recebem em suas casas as duas louvações: as festas se interpenetram de várias maneiras Para que bem se entenda, tanto Vila Seca como Criúva têm a sua própria igreja central, interligada a uma rede de capelas, com dioceses respectivas que centralizam a coordenação global da preparação. Vila Seca conecta-se à diocese de Caxias do Sul e Criúva é ligada a esta instância religiosa da cidade de São Marcos.

\footnotetext{
${ }^{6}$ Desde 2012, essas duas festas também envolvem de algum modo a Festa do Divino que acontece no bairro Sagrada Família. Este bairro, em zona urbana de Caxias, é dito como sendo a localidade de moradia mais usual para quem sai do campo e vai para a área urbana.
} 
Desde o princípio dos trabalhos empíricos de busca do entendimento dessa paisagem, entendeu-se apropriado fazer esse movimento no sentido de que as pessoas que moram nos distritos de Vila Seca e Criúva pudessem ter a sua visão de mundo - a sua paisagem, compreendida através da busca de como é o lugar onde vivem. Fica clara a escolha de sensível emprego: a perspectiva do lugar, que exige atenção ao ponto colocado por Escobar (2005: 70) - da sua necessidade de explicação histórica. E igualmente ao que também é mencionado por Mitchell (2001) e Massey (2000) - de que tal opção teórica exige considerar o conflito local/global centrado no recorte espacial da abordagem, bem como focar atenção ao nível de tratamento na pesquisa, no que tange aos sujeitos em foco - pois existe o perigo de se fazerem registros quase individuais de narrativas. A proposta é reforçada pela reflexão textual de Lucy Lippard (1997: 9 tradução livre nossa): "Espaço define a paisagem, onde o espaço combinado com a memória define o lugar."

O resultado formal do trabalho de pesquisa é encontrado no universo das possibilidades de construção de uma narrativa de paisagem. Encontram-se importantes subsídios em Potteiger e Purinton (1998: 3), que esclarecem que esse processo refere-se tanto a uma estória que é contada, quanto à maneira e aos cuidados utilizados para comunicá-la. Explicando a partir dessas características processuais suas potencialidades compreensivas e inclusivas, os autores comparam a seleção e a ordem de comunicação dos eventos a serem incluídos como o que ocorre no ato deliberado de construção de uma frase - o sentido final dessas escolhas depende.

Sobre essas narrativas, eles ainda dizem que a relação e jogo entre a paisagem e a narrativa acontecem pelo entrelaçamento feito pela experiência vivida. Digno de especial nota no que aqui se constrói, são suas afirmações de que "lugares configuram narrativas", e que a "paisagem não apenas localiza ou serve de pano de fundo para estórias, mas ela própria é uma figura e processo plena de movimentos e mutante, que engendra as estórias". Adicionalmente, afirmam que as narrativas de paisagem podem ser entendidas não apenas como sendo literalmente descritivas de uma realidade ou textos que devem ser lidos, mas como elas mesmas sendo integrantes do processo que, antes de tudo, conforma a paisagem, não só pela narrativa em si, mas, sobretudo, pelo papel dos leitores na produção de significado (Potteiger e Purinton, 1998: 5, 6 tradução livre nossa). 
Desta forma, os ricos aportes dos autores de Landscape Narratives auxiliam não a escolher um de seus vários modelos estudados e cuidadosamente sistematizados, mas a reforçar uma pretensão de início debilmente delineada. Consegue-se entender que há de se encontrar uma maneira de entender (e relatar) que lugar é esse exatamente que se pesquisa. Sabe-se que este ato - o de contar estórias da paisagem - está inserido em um processo de acesso à memória como "um reino intertextual”, em dispersões individuais que, no entanto, podem ser reunidas para a criação de identidades coletivas. Essas memórias, ou "texturas", são ditas como sendo capazes de "cortar caminhos e redes através do tempo", tecendo a paisagem muitas vezes a partir de lembranças "ancoradas no lugar pela associação com eventos ou práticas comemorativas explícitas" (Potteiger e Purinton, 1998: 58 - tradução livre nossa).

Por fim, é fundamental esclarecer outra vertente teórica de reflexão presente nesta pesquisa desde seus primeiros passos e que é bem traduzida pelo que Don Mitchell escreve a respeito de estudos de paisagem: eles "não podem mais apenas ser sobre paisagem". Pois a importância da paisagem é tal, que não mais permite que continue sendo "o trabalho de sonho - ou a base - do império". Ao invés disso, o geógrafo americano diz que os estudos de paisagem "devem ser dedicados a ver que a paisagem torna-se a base - e o trabalho de sonho - da justiça” (Mitchell, 2003: 793 tradução livre nossa).

O compromisso é claro: buscar a narrativa de paisagem de um lugar. Evitando as armadilhas românticas ao longo de sua construção, porém atentando-se à riqueza compreensiva que pode estar oculta nesse acesso ao "reino da paisagem". Tem-se consciência não somente do desafio de construção de sua estória, mas também de seu "histórico" (destaque nosso) poder conformador - como Potteiger e Purinton (1998: 17) enfatizam, ela pode também ser uma parte da criação deste domínio cultural.

Finalmente, é necessário dizer que muito cedo se percebe a importância do olhar e de seus registros na recomposição dessa narrativa. Por conta disso, um conjunto grande de registros imagéticos de vários tempos trama o resultado que o trabalho enfim constrói no espaço de hoje: cartografias históricas e contemporâneas, fotos de satélite, fotografias (feitas ao longo do trabalho de campo e de acervos) e reproduções de pinturas. E desse modo, quando se recompõe o que se viu, o escrever em si só não parece suficiente para bem conseguir narrar a paisagem que se encontra no lugar: gerase um estudo cartográfico comparativo e várias fotossequências para dar conta da intensidade visual do que se experiencia no campo empírico de estudos (Ribeiro, 2014). 


\section{Festas Para Muitas Cores: o Caso dos Brancos, Morenos e Amarelos}

No sistema agrário colonial consolida-se a Festa do Divino Espírito Santo. É o acontecimento mais grandioso em um calendário de muitas outras festas religiosas (para o padroeiro de cada uma das muitas capelas), como sequência de festejos tal como hoje conhecida, "considerados como rituais de caráter entre o religioso e o folclórico" (Brandão, 1978: 15).

Inicialmente inserida na paisagem no sistema agrário sesmeiro quase como uma iniciativa particular, estende-se paulatinamente a festa do Divino à comunidade, igualmente em Criúva e Vila Seca. Explica Júlio ${ }^{7}$, de 78 anos, vivendo da agricultura em Criúva desde que nasceu, que algumas pessoas do lugar foram buscar o sino da igreja em Porto Alegre, de cargueiro - no início nem igreja tinha. A citação expõe suas lembranças de tenra infância (em torno de 1930): “[...] tinha a tal festa do Divino; quando eu era bem pequeno, a bandeira do Divino passava. Eles vinham a cavalo, aquele pandeireiro - tinha um ou dois... tinha um velho que botava a bandeira enfiada por baixo da perna e ele mesmo batia o tambor".

Rudi, agricultor de 47 anos, nasceu em Criúva, mas bem perto de Vila Seca. Também tem bem presente a batida do tambor, em grupos a cavalo. Adiciona que esta função - um misto de devoção e diversão - durava dias, e que, para isso, os agricultores deixavam de lado toda a lida: só ficavam em casa os pequenos e as mulheres.

Júlio resume vários importantes aspectos a respeito da origem das festividades: das várias bandeiras do Divino que chegam à região na época das sesmarias, em trânsito de pessoas entre os Campos de Cima da Serra e a região litorânea de Santo Antônio da Patrulha - onde, originalmente, os colonizadores portugueses aportam a devoção vinda de seu país de origem. Detalha Júlio ainda a cobiçada doação de animais vivos para a festa - os terneiros sempre os mais esperados, secundados por ovelhas, porcos e galinhas -, e do contato com os vizinhos que esta prática proporcionava. Em um primeiro momento, a visita às casas era o ponto alto da louvação: as propriedades eram muito distantes umas das outras, e só no transcorrer dessas práticas festivo-religiosas é que se conheciam melhor. Adiciona o interlocutor que o interesse maior "era a homenagem ao Divino Espírito Santo: para pregar a religião - não era a exploração de fazer dinheiro", e havia mesmo casos de doações aos vizinhos muitos pobres, "que

\footnotetext{
${ }^{7}$ Optou-se pelo anonimato dos interlocutores, a partir de combinação inicial de conduta ética da pesquisa, registrada em Termo de Consentimento Livre e Esclarecido. Todos os relatos são de 2013. Ribeiro (2014).
} 
moravam em casebres". Longa conversa com Carlos, nascido em uma das localidades de Criúva na década de 1940, esclarece que a imagem do Divino saía da casa do festeiro, que se responsabilizava pelas despesas - "aquele festeiro pagava tudo - se ganhava, ganhava, senão ele entrava com as despesas e o "baile velho" (grifo dele) era meio no campo aberto, era tudo assim meio no improviso". As primeiras grandes festas que ele recorda eram aquelas nas quais a bandeira ia à região da colônia em Criúva, há mais de 60 anos. Após essa época, ele registra que houve um tempo quando as grandes louvações (dez dias, nove novenas) cessaram, sendo substituídas por um tríduo (festividades de somente de três dias).

A grande mudança acontece com a chegada do padre Pedro Rigon, em 1971, que nesta época resolve, "dar uma melhorada no que já existia", segundo Carlos. O padre então pediu a colaboração de músicos do lugar, que compuseram as músicas que até hoje são utilizadas no contexto religioso da louvação. Ao mesmo tempo em que organiza esse aspecto, ele igualmente valoriza e estrutura o contexto recreativo ou profano, muito vigoroso e apreciado no lugar.

Os detalhes dos personagens e de seus rituais nessa louvação conduzida no lugar (cujo registro etnográfico não é o foco do trabalho empírico que se faz, centrado no reconhecimento da paisagem) guardam muitas similitudes ao descrito por Martins (1975) para o interior paulista, por Brandão (1978) para Pirenópolis, em Goiás, e para Itaipava, por Zaluar (1983). Em síntese feliz, Brandão (1978: 37, itálicos do autor) diz que "a Festa do Espírito Santo poderia ser reduzida a sequências simbólicas de atuações com graus diversos de formação ritual, distribuídas entre comemorações coletivas em situações de rezar, comer e 'festar'”,

Há uma disputa entre os povoados no que tange à primazia histórica dessas festividades. Segundo Carlos, Vila Seca realmente tinha uma imagem do Divino na igreja desde o seu princípio, há coisa de 100 anos. Mas ele ressalva que isso portava o mesmo sentido que todas as muitas igrejas da região guardam aos seus inúmeros santos: a festa maior de Vila Seca era a de Santa Teresa. Somente um pouco depois da retomada da festa em Criúva é que algumas pessoas da vila mais ligadas à paróquia católica decidem reavivar o festejo de forma semelhante - isso acontece lá por meados dos anos 1980. A partir desse fato é que realmente a festa tomou força, até tornar-se o que é hoje. Esse relato é coerente ao que Paixão Cortes registrou em 1983, dizendo que Criúva era então o único registro de ocorrência da festa do Divino Espírito Santo - em 
sua plenitude de aspectos - no estado do Rio Grande do Sul. (Paixão Cortes 1983a; 1983b: 20).

Similitudes ao relato de Carlos são encontradas na análise da retomada da festa em Vila Seca feita por Otávio, que é nascido em meados da década de 1940 em Vila Seca. Ele recomenda que se fale com o pessoal de Criúva para entender o início dos festejos. Como ele detalha, "em Criúva a festa sempre foi muito forte, por que o padre Pedro era a chave". O interlocutor destaca com clareza as diferenças do processo de retomada das duas festas, colocando como a maior delas a origem das iniciativas a isto associadas. Em Vila Seca, a partir da comunidade, auxiliada por pessoas que já moravam em Caxias - "pois aqui a gente não tinha padre, foi mais por nós; a paróquia aqui é Ana Rech, então o pároco atende várias comunidades”. Em Criúva as ações partem da paróquia, pois “o padre estava sempre lá”.

O fato é que, nos dias que correm, a festa do Divino Espírito Santo em Vila Seca e Criúva parece vivenciar um momento especial, em que é visível a ampliação de sua abrangência e relevância. Os contatos que foram feitos com o arquipélago de Açores, as visitas dos festeiros a outros municípios próximos e os movimentos de integração das duas festas desses distritos rurais com o núcleo urbano de Caxias são importantes fatos nesta percepção contemporânea. Em Vila Seca entende-se que os rituais e figurinos dos festeiros encarregados da louvação ficam mais elaborados; a abrangência da louvação amplia-se, bem como o tamanho da festa, com sua organização tornando-se mais complexa e demandante.

Há, contudo, outras diferenças - além das encontradas na sua origem - entre os dois processos, nesse tempo e em outros, que são constantemente reconhecidas e valoradas. Exemplifica-se esse procedimento citando-se o que resume Rudi: "a gente gosta mais de Vila Seca, que faz a louvação. [...] passaram em todas as casas por aqui, e em outros lugares; não excluem casas. A organização deles é bonita, o pessoal é unido, trabalham para aquilo lá".

Juntamente com as festas religiosas, eram organizadas sempre uma ou mais refeições coletivas, almoços ou jantares festivos, que migraram da casa dos festeiros para os salões paroquiais, os quais paulatinamente foram sendo construídos com os lucros da arrecadação dessas festas. A organização, desse modo, vai passando para os religiosos católicos, que progressivamente instituem os fabriqueiros - as pessoas da comunidade leiga que trabalham nesses momentos. 
Por fim, ao se perguntar detalhes dos bailes das festas religiosas, desvela-se a diferenciação étnica que também faz parte dessa organização do lugar. Otávio fala que antigamente (não no tempo dele, portanto, há mais de 70 anos), nas missas estavam todos juntos, mas havia bailes separados para brancos, pretos e amarelos. O salão dos Medeiros (Hotel Medeiros) era o dos brancos e o salão dos morenos era "no Murgo, logo para lá" (pelo seu detalhamento entende-se que o local ficava na periferia da vila, quase na estrada que vai para Caxias). Havendo um entendimento razoável do que seriam brancos e pretos, ele explica que "[...] amarelo era o de cor de cuia, como chamavam [...]". Esclarece que, já no seu tempo, alguns homens brancos tentavam ir aos dois bailes. Mas o caso dos então ditos amarelos era distinto, como ele detalha: “[...] iam aonde aceitavam eles - no baile dos brancos talvez não deixassem, mas no dos morenos com certeza!”.

Arlindo, partindo da vivência de toda sua vida de religioso na região (também em Cazuza Ferreira e no Juá, vizinhança de Criúva e Vila Seca, os distritos de São Francisco), agrega particularidades importantes e amplia o entendimento desse fato da paisagem do sistema agrário colonial. Esclarece que não existiram grandes fazendeiros no lugar, mas sim uma especial atitude nessa direção. Diz ele que bastava alguém ter alguns hectares de campo para se considerar fazendeiro. Essa posse, em geral oriunda da época das sesmarias, somada ao fato de serem brancos, construía a tal atitude: "eles se consideravam ricos e não se misturavam". Essa "mistura" ele especifica que significaria, por exemplo, um casamento de alguém do campo com alguém da roça, "da colônia”, ${ }^{8}$ acontecimento de início muito raro e malvisto. Sem hesitação, Arlindo esmiúça a situação: os "que tinham terra comprada", pequenos e "misturados", esses, eram os amarelos. Ou seja, adiciona ele, a definição de amarelo era muito mais pela questão econômica do que por qualquer outra coisa - o amarelo é o "sujeito pé-dechinelo, que não tinha campo, não tinha lote de gado", eram os "agricultores". Explana que todos os fazendeiros, na época desse relato, eram lusos ou luso-brasileiros, e que "os fazendeiros do campo olhavam os negros e os amarelos de cima, isto é, com ar de desdém".

\footnotetext{
${ }^{8}$ As zonas de campo e a da colônia são informalmente definidas há muito tempo no lugar, e coincidem ao zoneamento do estudo dos sistemas agrários. Como Ribeiro (2014), distingue, a partir de diferenças de relevo, menos dobrado e acidentado na zona "dos campos", e de vegetação - as escarpas (peraus) da zona de colônia eram originalmente recobertas pelos "matos", formação bem mais esparsamente encontrada na zona de campos.
} 
Pelo que se depreende a partir do relato de Arlindo, a festa da padroeira da igreja era sempre a dos brancos e ricos, os fazendeiros; havia aqui e ali a festa de Nossa Senhora do Rosário, dos pretos, e, segundo ele, a festa de Nossa Senhora Aparecida, que seria a festa dos agricultores. Depreende-se de seu rememorar que se repetia a mesma estrutura de festa (a programação religiosa em paralelo ao festivo, ou seja, o profano), mas com festeiros diferentes, em momentos e espaços distintos: "O baile da festa (da padroeira), se eu não estou equivocado, o baile da festa dos ricos, era na dita sociedade, que era um pavilhão, o da sociedade dos ricos; e o baile da festa dos amarelos e dos negros era no salão da igreja." Nas refeições festivas, conta ele que, uma vez pagando, todos podiam entrar. Porém, era no momento da dança que a restrição aparecia por inteiro, como mostra a citação: “[...] naturalmente... em baile de branco, 'negro não entrava' - isso era a coisa mais natural! Podiam participar da festa, mas quando se tratava do baile, não! Baile de negro não entra branco, baile de branco não entra negro!". Já no caso dos amarelos, a natureza mudava um pouco, segundo Arlindo: “[...] em baile de amarelo, tudo bem... era um pouco mais condescendente...".

E a partir desse detalhe que emerge do lado profano da festa, chega-se na descrição da vida das pessoas do lugar, na paisagem desse sistema agrário sesmeiro e no seu desenrolar no posterior período colonial. Arlindo conta que muito raro era que os negros (filhos e netos de escravos) tivessem algum pedaço de terra. Pois ocorreria por posse ou através de compra (dois processos financeiramente onerosos, e, por isso, praticamente a eles interditos), ou como herança, algo muito raro. Enfim, diz que, mesmo se tivessem terra, sua "condição de vida era muito difícil", adicionando que, excetuando-se os fazendeiros, todos eram pobres, mas "que, normalmente, os negros eram mais pobres.".

Cabe aqui citar o que Carlos Rodrigues Brandão tem presente ao início de sua profunda análise antropológica da Festa do Divino Espírito Santo a partir do seu estudo empírico realizado em Pirenópolis. A ideia do que são exatamente os principais atributos de comemorações de caráter folclórico-religioso: "a festa é um ciclo que percorre ao longo do tempo, paralelamente e de modo simbólico, o próprio ciclo de rotina e de trabalho da sociedade" (Brandão, 1978: 16). A imensidão do seu trabalho não cabe aqui, mas a citação de um pequeno extrato de seu texto auxilia a entender o que Arlindo desnuda nessa paisagem do lugar. 
Aparentemente reunidos sem muita ordem para compor - entre religiosos e profanos - os momentos festivos de "culto ao Divino", os rituais da Festa do Espírito Santo reproduzem simbolicamente a própria ordem da sociedade, as suas relações de trabalho e prestações de serviço derivadas, entre tipos de agentes sociais; assim como as contradições que, por vezes, a própria sociedade encobre e a Festa consegue desvelar. (Brandão, 1978: 51- destaques do autor).

\section{Seguindo a louvação do Divino Espírito Santo}

A observação participante permite conhecer a complexa articulação comunitária anterior ao ciclo festivo do Divino Espírito Santo. Uma primeira instância dessas atividades está ligada às pessoas responsáveis pela condução da louvação propriamente dita: o dito "grupo de festeiros", os músicos e uma pessoa investida de poder religioso (ministro leigo, no caso de Vila Seca, e o pároco, no caso de Criúva). Outra esfera de organização, mais diretamente ligada aos religiosos locais, conduz os "preparativos operacionais" da festa: os bailes, almoços e jantas comemorativos e ritos religiosos missas e procissões. As pessoas que fazem esse trabalho são conhecidas como "fabriqueiros" - de maneira similar aos festeiros, doam seu tempo e trabalho para a comunidade. Ainda há outra instância dessa esfera comunitária, também ligada aos festeiros, que organiza a cavalhada, outro evento desse ciclo festivo.

$\mathrm{O}$ reporte final das atividades empreendidas é feito com base em duas fontes documentais: o Caderno de Campo, no qual foi registrado o dia a dia da pesquisa e suas reflexões, e o Caderno de Ofertas do Divino de 2013, que contém o registro de todo o ciclo de louvação. Neste último, foram cuidadosamente registradas as "andanças" coletivas dos festeiros de Vila Seca em 2013, que totalizaram em torno de 4.300 quilômetros, com 464 assinaturas nele recolhidas. Em Caxias do Sul, foram visitadas várias localidades - adicionalmente a Vila Seca e Criúva, também Ana Rech, Santa Lúcia do Piaí, Fazenda Souza, Vila Oliva, Quarta Légua, centro de Caxias do Sul e outros distritos. Além disso, a louvação visitou os municípios de São Marcos, São Francisco de Paula, Sapiranga, Farroupilha, Flores da Cunha e Porto Alegre.

A observação participante acompanhou os momentos em que foram colhidas 145 assinaturas, ao longo de 1800 quilômetros percorridos. Em sua totalidade, igualmente englobou a participação na missa de reis na localidade de Criúva e da Festa do Pinhão de Vila Seca. Complementarmente a essas atividades, foram posteriormente realizadas 32 entrevistas: do tipo semiestruturado, em conversas mais longas que foram 
sendo constituídas de acordo com as reflexões que paulatinamente foram sendo construídas no Caderno de Campo.

A inserção etnográfica no grupo de louvação era sempre anunciada, com breve explicação do ministro que conduz a louvação, apresentando espontaneamente a pesquisa da Universidade Federal e seu intuito. Adequado julga-se explicar que as pessoas em Vila Seca e Criúva, conforme percebido, ficam bastante receosas ao escutarem menção de qualquer tema que rescenda levemente a qualquer tema ambiental. Porém, relata-se que algum ligeiro mal-estar às menções desse tipo na apresentação era logo francamente revertido por explicação sobre a intenção da participação na louvação: de justamente buscar um modo de entender melhor o que as pessoas do lugar pensam a respeito dessa relação de suas vidas e da natureza que as envolve. Este esclarecimento trazia imediato entendimento de que a pesquisadora não era contratada de ninguém, o que possibilitou que a proposta de pesquisa fosse muito bem recebida ao longo de todas as visitas que foram feitas nas atividades de observação participante. Adicionalmente, em vários momentos em que se seguiu a bandeira (em geral conduzida pela dona da casa) e o ministro na benção da casa, pedia-se licença adicional, para tal e para os registros fotográficos, de áudio e vídeo que foram feitos - nesse momento, intuitivamente coletados. Muitos contatos para entrevistas posteriores foram assim feitos, em função da riqueza de relatos antevista nas muitas louvações acompanhadas. Como sublinha Rudi, em Vila Seca "todos conversam uma vez por ano, é bom", similarmente ao dizer de Júlio, em Criúva, "através do Divino eles conheceram os vizinhos; os festeiros fazem uma amizade muito bonita, eles andam por tudo".

Evidenciam-se nesse contexto as quatro grandes variantes de contatos periódicos comunitários que foram presenciadas no lugar, devidos ao acompanhamento do grupo de louvação que realiza o convite para essas festividades religiosas. ${ }^{9}$

Existem, então, as visitas às autoridades, que muitas vezes aceitam o convite feito pela louvação, comparecendo às missas e às demais atividades festivas. O que resultou, em algumas das ocasiões testemunhadas, em pronunciamentos de cunho político. Desse modo foi que se presenciou o anúncio da inclusão da Festa do Divino

\footnotetext{
${ }^{9}$ Em Caxias do Sul foram acompanhadas visitas a: estabelecimentos comerciais e industriais de zona urbana; prefeitura, quase todas as secretarias municipais e câmara municipal de vereadores; autarquias que tratam do saneamento e da gestão de resíduos sólidos; Universidade de Caxias do Sul, seu hospital e televisão; um asilo, uma escola para crianças portadoras de necessidades especiais; Rede Brasil Sul de Comunicações (jornal e televisão); e, finalmente, em Porto Alegre, ao Palácio do Governo e à Assembleia Legislativa.
} 
Espírito Santo no calendário oficial de eventos do Estado, pleito que teve acolhida em visita pela louvação de Vila Seca ao governador.

Ocorrem igualmente louvações em outros estabelecimentos de caráter variado na zona urbana que, embora etnograficamente acompanhadas em menor número, trouxeram um viés muito rico à pesquisa. Constatou-se que, se é garantida a atenção ao grupo por onde circula, a receptividade não existe em todos os casos. Isso não passa despercebido às pessoas que o integram e acaba por suscitar uma série de comparações entre o urbano e o rural. Nesse caso, entre a cidade e os campos, sendo que a expressão "os campos" é a referência unânime para designar o rural no lugar. Escutam-se questionamentos sobre qual seria o maior objetivo do que se está a fazer, e se não valeria muito mais a pena realizar a louvação só nos campos, pois lá as pessoas são sempre bem recebidas. A zona urbana do município, a bem da verdade, é procurada porque garante boas doações, necessárias para que se faça uma "boa festa" - pois cada conjunto de festeiros que assume quer fazer uma festa melhor do que as que já foram feitas até então.

Também existem vários momentos públicos devocionais e festivos coletivos (pois nas louvações nas casas também existem esses dois lados), que complementaram a compreensão do ciclo festivo pela imersão nos atos religiosos e profanos em si. A devoção é comunitariamente manifestada nas missas semanais normais, oficiadas em várias capelas espalhadas pelos locais visitados, que também honram a presença do grupo de louvação. O mesmo ocorre nas missas com ritual especial para o ciclo (incluindo as ditas missas crioulas), em datas inscritas no calendário da festa. Em adição a esses eventos, acontecem as procissões, sendo uma delas uma cavalgada. Os cavaleiros realizam um percurso de um dia a outro, partindo do Santuário de Caravaggio, em Farroupilha, e tendo como ponto final a igreja de Vila Seca, passando no centro de Caxias do Sul e na zona rural nesse trajeto. Já os momentos festivos são constituídos pelos jantares dançantes e almoços, além do leilão dos animais doados para a festa.

Contudo, pode-se afirmar que a chegada da louvação às casas, principalmente nas da zona rural, é o momento do ciclo de festividades mais referido pelos habitantes do lugar, mobilizando indistintamente homens e mulheres de todas as idades. Festeiros e músicos, seguindo um ritual característico, levam a Bandeira do Divino Espírito Santo aos visitados, realizando o convite para a festa e pedindo também uma contribuição para a sua efetivação. Para essa atividade, cumpre-se a cada dia uma programação informal 
que é definida no início da jornada dos festeiros, agrupando as visitas intencionadas por critério de proximidade, visando maximizar o número de louvações feitas por vez. Não são visitas muito longas, pois são muitas a serem feitas - em pouco tempo, com a familiaridade propiciada pelo rito religioso e pela camaradagem de pessoas que se conhecem de longa data, fala-se só de coisas que importam para quem ali se encontra. Rememoram as perdas de entes queridos, rezam por alívio de dificuldades de toda sorte, agradecem por saúdes recuperadas ou por tempos melhores - aparecem as doenças, a violência (roubos, assaltos e mesmo sequestros), a solidão da velhice desamparada, os problemas com drogas - não há tempo nem energia perdidos em assuntos superficiais ou preâmbulos descartáveis, vai-se direto ao ponto.

A paisagem fica bem colorida, marcada pelo encontro dos predominantes verdes do mosaico campo e floresta com o majoritário trio vermelho-branco-azul da bandeira, reproduzido e animado ao longo do ritual que é levado a cabo, como a narrativa imagética das figuras 2 a 14 expõe.

É um momento de intensa comoção. Muitos sentidos são conjuntamente acionados quando as várias pessoas da louvação e da casa que a recebe se encontram nesse último caso, muitas vezes, o casal dono da residência. A intenção uniforme de boa apresentação do grupo é evidenciada por suas vestes. Elas são cuidadosamente escolhidas e confeccionadas a cada temporada de louvação, e a escolha do figurino é feita de acordo a cada tipo de visita a ser feita. Ao menos três combinações distintas de roupas foram distinguidas - uma informal (a que figura na sequência apresentada), outra cerimoniosa e uma festiva.

Apesar da riqueza do conjunto fotográfico, é justo que se tente dizer algo do que esse recurso por si só não traduz. É o caso dos gestuais sinceros e diretos de saudação e reconhecimento - os abraços vigorosos, beijos afetuosos e frequentes lágrimas de emoção. Outro mundo que não cabe nas fotografias é composto por muitos sons que acompanham essa atividade: os musicais - dos instrumentos (gaita, violão e bumbo) e das vozes, que cantam em uníssono as cantorias de cada movimento do ritual. Secundados pelos ditos dos benzimentos e das rezas, acompanhados de intenso e específico gestual a cada um desses momentos.

Após a forte cena emotiva acionada pela chegada dos festeiros com a bandeira, sucede-se a festiva ocasião das ofertas dos donos da casa. Além de sua doação registrada no "Caderno de Ofertas do Divino", há sempre a oferta de bebidas e comidas aos festeiros. 


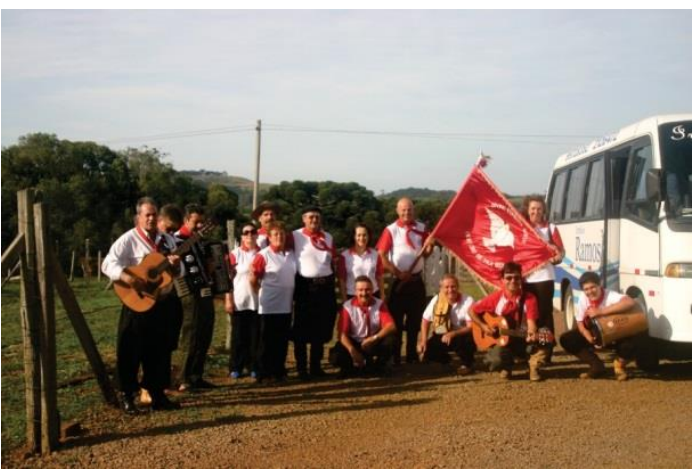

Figura 2: Louvação do Divino Espírito Santo chega - festeiros, músicos e ministro.

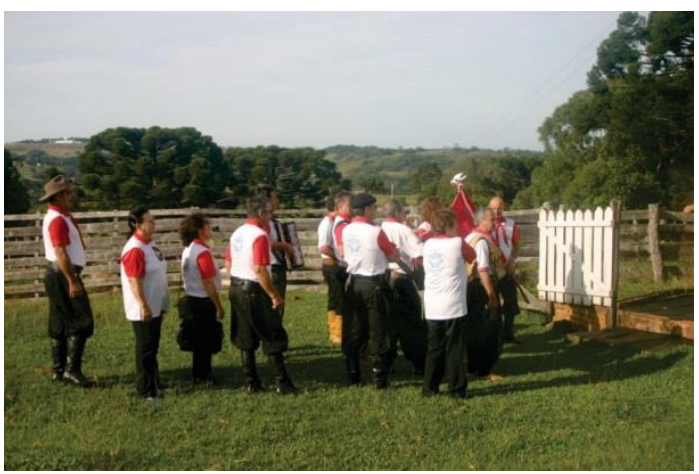

Figura 4: Cantam Ô de casa.

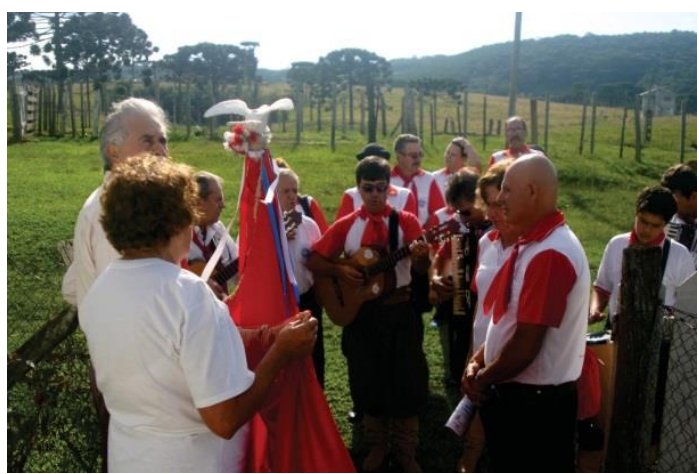

Figura 6: Convidando e pedindo oferta - festa do Divino Espírito Santo de Vila Seca.

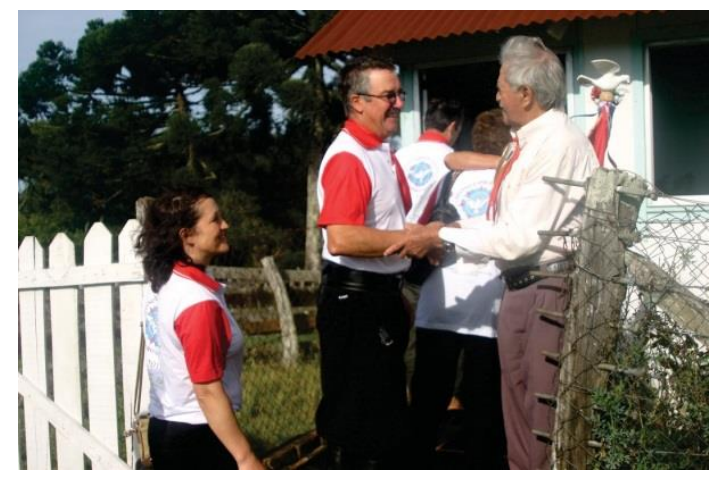

Figura 7: Festeiros saúdam os donos da casa.

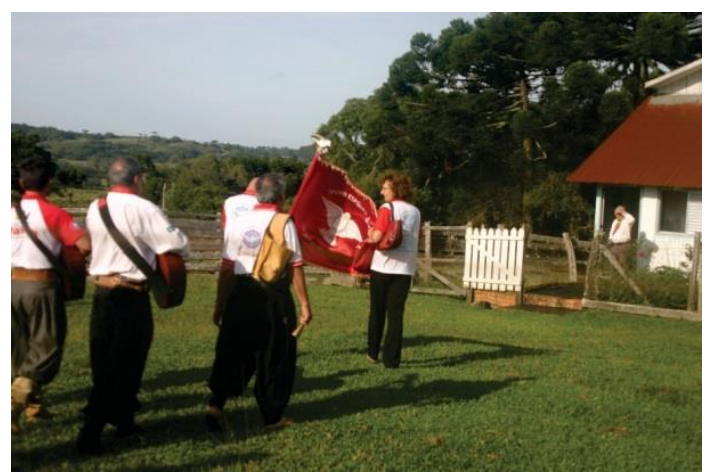

Figura 3: Aproximam-se do portão, festeiros de honra à frente.

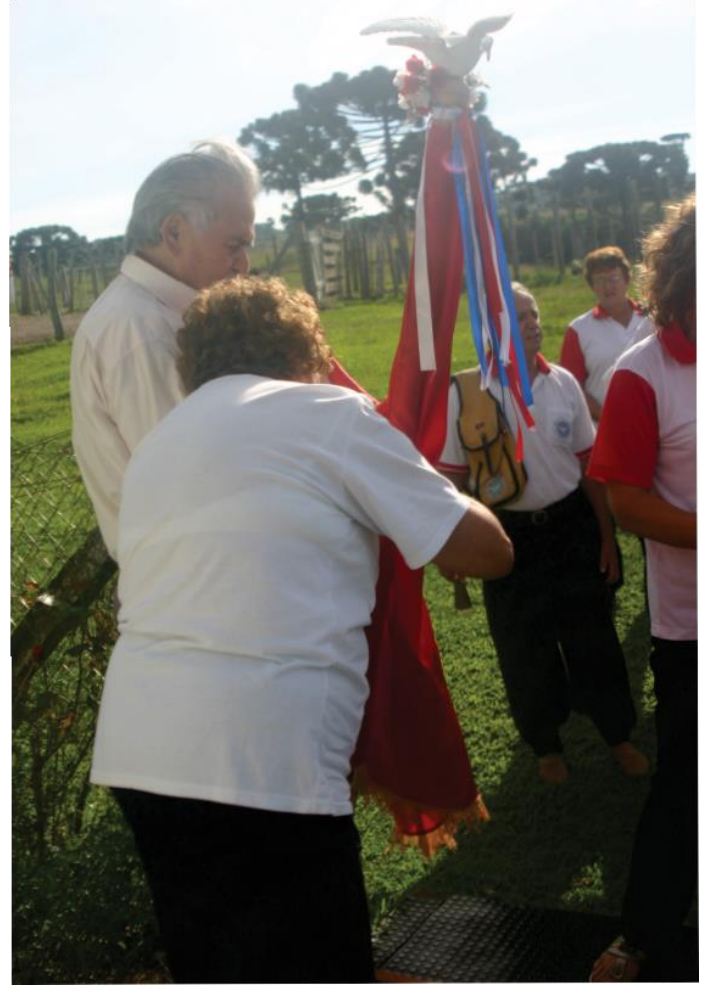

Figura 5: Casal dono da casa recebe a bandeira do Divino.

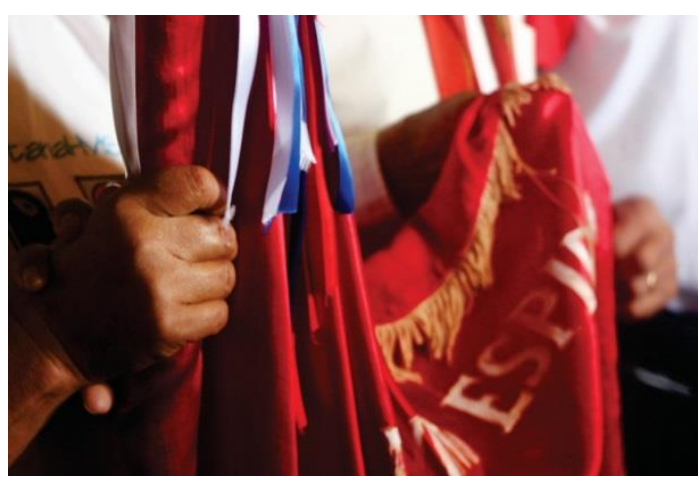

Figura 8: Rezas primeiro, depois ofertas.

Fontes: 2 a 8, Claudia Ribeiro (2013); Vila Seca. 


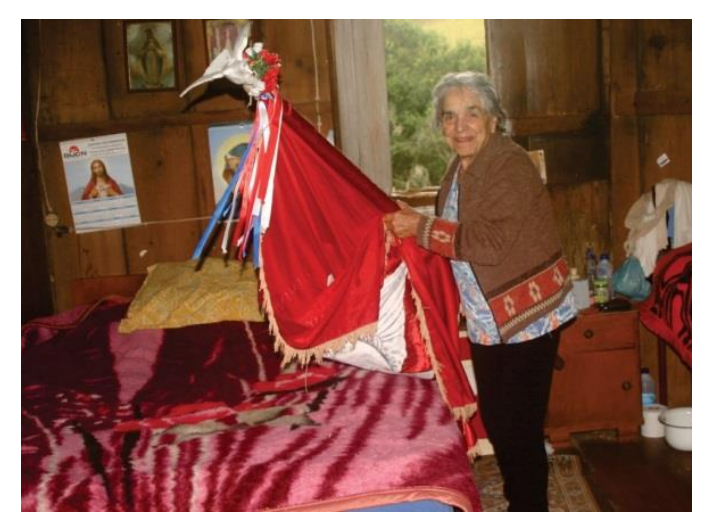

Figura 9: Bênção para toda a casa.

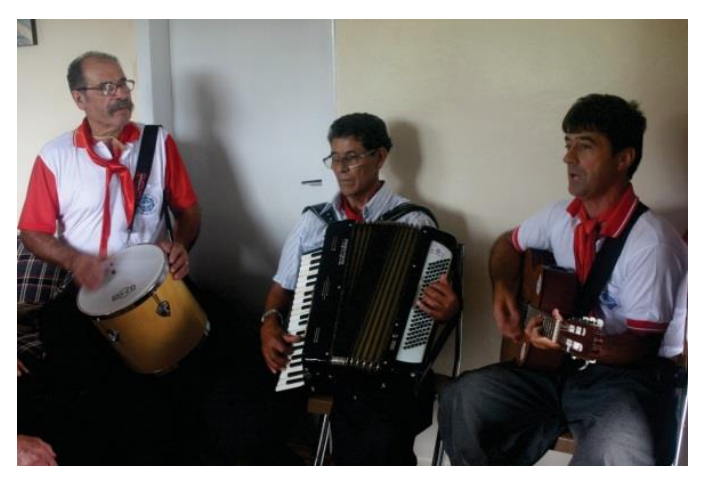

Figura 11: Agradecimento.

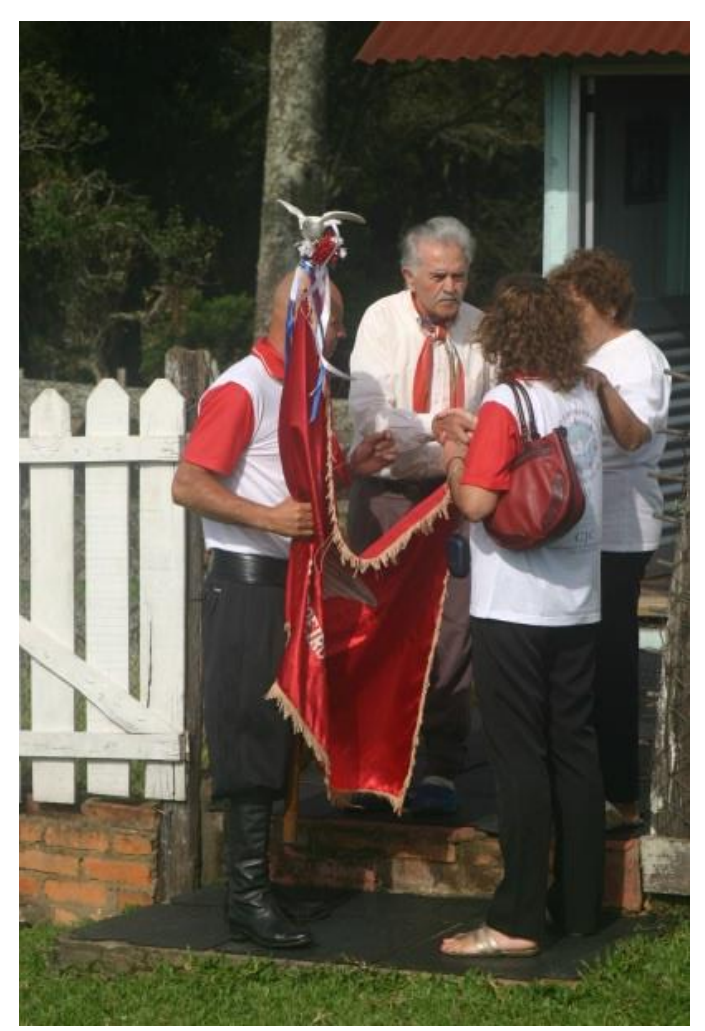

Figura 13: A devolução da bandeira do Divino.

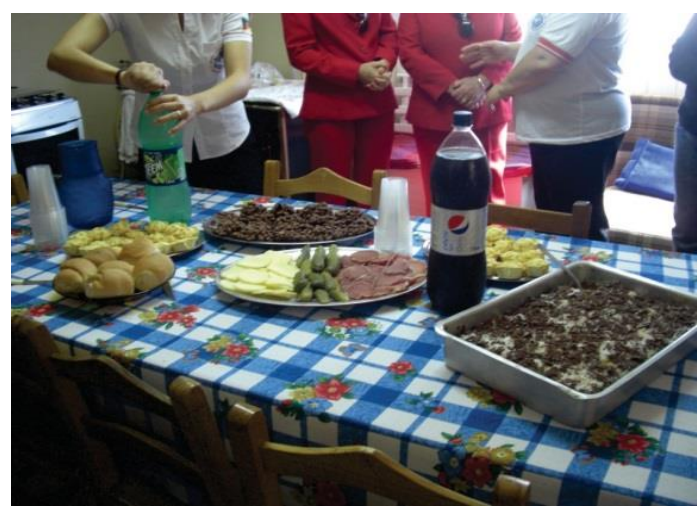

Figura 10: donos da casa oferecem comes e bebes ao grupo de louvação.

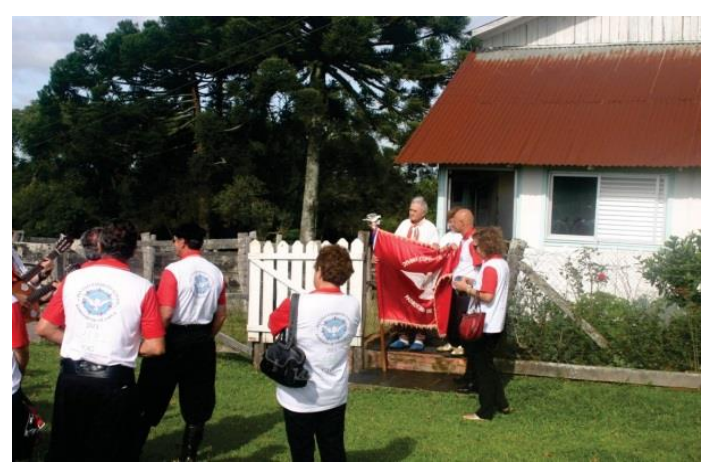

Figura 12: Despedida.

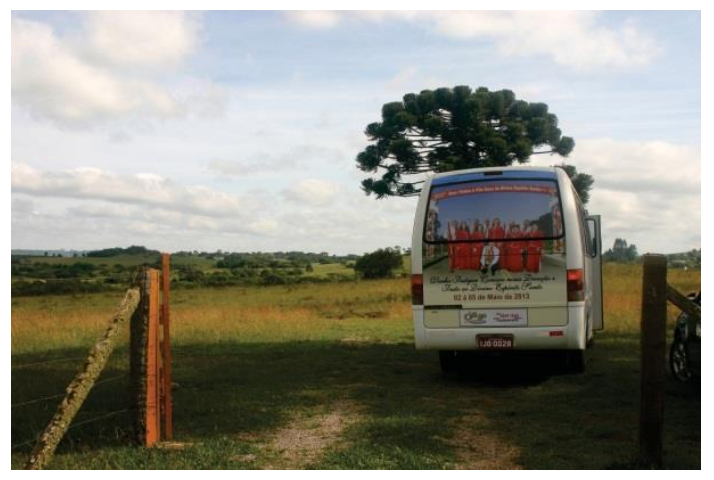

Figura 14: Saindo para outra louvação.

Fontes: 9 a 14, Claudia Ribeiro (2013); Vila Seca. 
Não raro mesas fartas estão à espera dessa visita do grupo, que retribui com alguma cantoria profana, do gosto do dono da casa, antes do encerramento religioso da louvação - a despedida. A oferta para a festa é variada, dada de acordo com as posses dos visitados, e não é nem de longe a arrecadação maior da festa - os valores das doações registradas no caderno cobrem apenas os custos do transporte dos festeiros. $\mathrm{Na}$ verdade, a maior arrecadação é obtida com a venda da rifa da festa, que também é ofertada nesse momento (mas não registrada no caderno). Todos enfatizam que a oferta não é o maior objetivo do momento ritual, mas sim levar a devoção aos simpatizantes. Inclusive, em situações de menos posses, o ministro leigo que conduz a louvação enfatiza de que esse ponto não é importante. Porém, quando se sabe possível, as canções pedem "um terneiro" logo na chegada - a doação mais emblemática e cobiçada.

As visitas aos campos foram todas em sábados, domingos ou feriados, em longas jornadas - começavam-se os trabalhos por volta das sete horas da manhã, ultrapassando não raras vezes a marca das 22 horas.

Dessa forma é que a casa (e a propriedade) literalmente abre suas portas à bandeira do Divino - pois ela deve passar por tudo: efetivamente todas as peças da casa, todos os galpões de todos os tipos de animais, os carros e tratores, os locais de preparo e armazenamento do queijo serrano e outros processamentos agroindustriais locais. Há alguns procedimentos rituais que são seguidos - mormente pela dona da casa (que é quem conduz a bandeira na maior parte das ocasiões, salvo doença ou outro impedimento). Os atos de depositar a bandeira sobre as camas e a mesa de refeições e envolver uma pessoa adoentada com o estandarte do Divino foram vistos várias vezes. Igualmente recorrente é a oferta da bandeira para ser beijada com reverência - quando do seu recebimento e devolução ao casal de festeiros "de honra" que ciosamente a carregam. Oferece-se às pessoas presentes a mesma oportunidade, contudo de forma não impositiva, pois nem todos os presentes são devotos da mesma forma.

Tudo isso acontece cercado por um alarido permanente, evidenciando o que Brandão (1978) bem resume: muito se come e se reza, mas também muita festa se faz. As muitas piadas e frases de duplo significado, e mesmo a realização de pequenos bailes domésticos ao fim das rezas, evidenciam o tempo todo que o profano e o religioso andam muito juntos. E existem as variações de atitudes que se observam - tanto com relação ao conjunto de pessoas que inteira o grupo da louvação, quanto no que diz respeito ao pequeno aglomerado que aguarda na porteira do jardim ou na porta de casa. As pessoas reagem de formas bem distintas, configurando claramente múltiplas 
situações na paisagem que se percorre. Escutam-se, por exemplo, reclames sobre muita ou pouca reza, e muitos e variados comentários relacionados às lembranças acionadas pelo encontro que acaba de ocorrer, ou mesmo no que tange aos fatos recémpresenciados nas propriedades visitadas. De acordo ao que Zaluar (1983) analisa, observam-se sutis diferenças de engajamento, com gradações na participação nos rituais e procedimentos do ciclo festivo, refletindo, em certa medida, a observação da autora de reprodução de uma hierarquia "condizente com a posição de classe". Diz-se aqui, que se notou que essa posição, embora seja muito consciente, não é do agrado de todos.

\section{“Ô de casa" em todas as portas?}

Ao final das atividades de observação participante ao longo do ciclo festivo, percebe-se que, sim, a bandeira do Divino abre muitas portas do lugar. Mas não bate em todas elas, e outras tantas não se abrem à sua passagem. Não por falta de vontade, pois o esforço empreendido é hercúleo, mas simplesmente porque é desse modo que as coisas acontecem, por diversas razões. Na medida em que as muitas pessoas com quem se conversa intuem o universo que a pesquisa busca conhecer, recebem-se "recados" apontando a necessidade de se ver que "[...] algumas coisas ficam fora desse processo $[\ldots] "$.

Em função também disso, a reflexão paulatinamente elaborada no caderno de campo apontou para a necessidade de realizarem-se esforços adicionais na direção do que se procurava - em grandes linhas, a apreensão mais completa da relação da paisagem com a ruralidade. Essa foi a origem dos cuidados adicionais para garantir a escuta de homens e mulheres, pessoas jovens e mais maduras, bem como da atenção especial para a detecção das singularidades de Criúva ou Vila Seca. E, mais do que tudo, conformou a busca de complementação com relação a outros dois pontos desse intuído universo de alteridades: a questão étnica (já antevista nos estudos exploratórios dos sistemas agrários) e os movimentos comunitários que acontecem fora da esfera religiosa.

A entrevista feita com Arlindo, ao final do ciclo festivo, muito contribuiu para uma análise diferenciada da retomada da festa do Divino nos distritos. O seu primeiro enfoque de entendimento vê a festa como um aglutinador de relações, em que as manifestações religiosas se tornam também "manifestações de encontro das pessoas em uma sociedade individualista". O segundo viés que ele coloca é relacionado à sua 
atividade. Ele visualiza nas festividades a retomada da dimensão religiosa, mas dizendo que ali ela "também anda colocada entre parênteses". Com isso, o interlocutor manifesta o seu temor de a devoção popular "esclarecida ou semiesclarecida reproduzir a imagem do Espírito Santo como um santo a mais na igreja", ao mesmo tempo em que vê a fé sempre positiva, embora seu exercício formal nem sempre seja inclusivo. Com relação ao contato com pessoas de outras crenças, ele é taxativo, estabelecendo uma relação direta com o meio: "pode ser, mas tenho dúvidas, porque 'o meio, o meio da devoção ao Espírito Santo’ não é um meio muito eclético" (destaque nosso). Esclarece novamente que este meio, o da festa do Divino ${ }^{10}$, é inclusivo com relação ao pensamento de que ali as origens açorianas e italianas estão "mescladas". No entanto, esclarece ele, não no sentido de aceitarem o convívio com outras crenças e, junto com elas, outras etnias. A conversa avança e alcança-se melhor o viés étnico do que acontece, além da dimensão religiosa: "fica muita gente de fora - se perceber, nas Festas do Divino, pode ser que eu me engane, mas a maioria é branco. Isso é uma história longa também na minha terra, sim, sim, são brancos - na festa do Divino é branco...".

O interlocutor fala de pessoas "de outra fé", que estão em outras festas (como já citado anteriormente) e mesmo em outras devoções. Adiciona que acredita que os escravos podem ter contribuído para o sincretismo, e mesmo, segundo ele, um pouco de espiritismo foi nascendo aos poucos: "e hoje, nem se fala; mas originalmente, falo de 20, 30 anos atrás - era estranhíssima uma confissão religiosa cristã, Assembleia de Deus, estranhíssima... São Benedito, algumas entidades que eu vi - São Jorge; outras coisas relacionadas à questão africana, tudo junto, com o Divino, sem falar nas benzedeiras". Arlindo conta muitos e ricos detalhes a respeito dessas pessoas que têm essa "espiritualidade - esse dom no seu jeito de ser", que surgem em uma dimensão espaço-temporal definida como "no campo perdido no meio do nada". Nesse ponto da paisagem, as figuras de uma religião instituída - os padres católicos - só aparecem muito tempo após. Ele comenta sobre as normalidades do lugar: "ao se perder uma rês, acender uma vela para o Negrinho do Pastoreio... isso era a coisa mais normal, assim como dizer que ia fazer isso". E na despedida da conversa, com um sorriso enigmático, Arlindo profere que “o Divino inclui, mas a festa do Divino não necessariamente...”.

\footnotetext{
${ }^{10}$ A notar a utilização da palavra "meio", com precisão berquiana, uma vez que inclui o elemento humano e sua subjetividade, diferindo, portanto, da delimitação ambiental.
} 
A busca desse entendimento mínimo do sincretismo local (posto não ser este o propósito do trabalho) traz ricas contribuições ao lado que fica de fora do Divino (expressão dos interlocutores, destaque nosso) - mas que, sem dúvida, está inserido na paisagem do lugar. Duas benzedeiras, pessoas já de idade avançada (em torno de 80 anos) - uma branca, a outra morena, uma em Criúva, outra em Vila Seca - enriquecem sobremaneira o conhecimento dos aspectos ligados a esses seus mundos. Diversos mundos, que ficam às margens da festa do Divino, mas não da devoção no Divino Espírito Santo, como se poderá entender um pouco melhor.

As duas mulheres são devotas de São João Maria: Fátima mostra-me a sua foto "do profeta de 180 anos" que, segundo os antigos, acampou no Rincão das Flores (localidade de Criúva, vizinha à Vila Seca). Luísa chama-o de São João Maria "da Mata”, e só benze a criação por seu intermédio. Outra estória coletada em Criúva detalha um ritual antigo envolvendo a foto do monge. Media-se um graveto do mesmo tamanho do cajado de João Maria, encostando-o na foto, e, ato contínuo, com ele benzia-se três dos quatro cantos da lavoura infestada por lagartas - segundo o interlocutor, "por este canto saíam todas as lagartas, chegava a ficar cheiro dos bichos mortos, era impressionante!".

A crença já havia sido registrada no levantamento fotográfico do IGTF realizado em Criúva em 1981, e o trabalho de campo evidencia sua vitalidade contemporânea, como evidenciam as figuras 15,16 e 17.

Segundo Queiroz (1977: 247), João Maria é comprovadamente um dos supostos vários monges ligados ao movimento messiânico do Contestado. Ligado à ruralidade cabocla de Santa Catarina e Paraná no início do século XX, fez parte, concretamente, das rotas dos tropeiros dessa época, com passagem pelo Rio Grande do Sul. A autora explica a sua origem, dizendo que se encontra num livro de inscrição de estrangeiros em Sorocaba, o registro de um italiano de nome João Maria Agostini, que ali chegou em 24 de dezembro de 1844, declarando de profissão eremita solitário, e que viria ao país “[...] em exercício de seu ministério [...]”.

Pesquisa mais recente escrutina a origem e trajetória do monge, explorando também em algum grau as crenças a ele relacionadas. Não somente em estreita ligação com as práticas das benzedeiras do lugar, mas também com configurações campesinas da ruralidade da paisagem em análise. Karsburg (2014: 43) acaba concluindo que João Maria poderia transitar igualmente entre os dois perfis que visualiza resultar dos estudos de muitos pesquisadores brasileiros. Um deles é o religioso: o de alguém com 
conhecimento evangélico só alcançado por alguém muito próximo à igreja. Porém, o que se encontra no campo de pesquisa é o perfil popular: o de um santo dos pobres e excluídos, porta-voz na luta contra as injustiças da sua época.

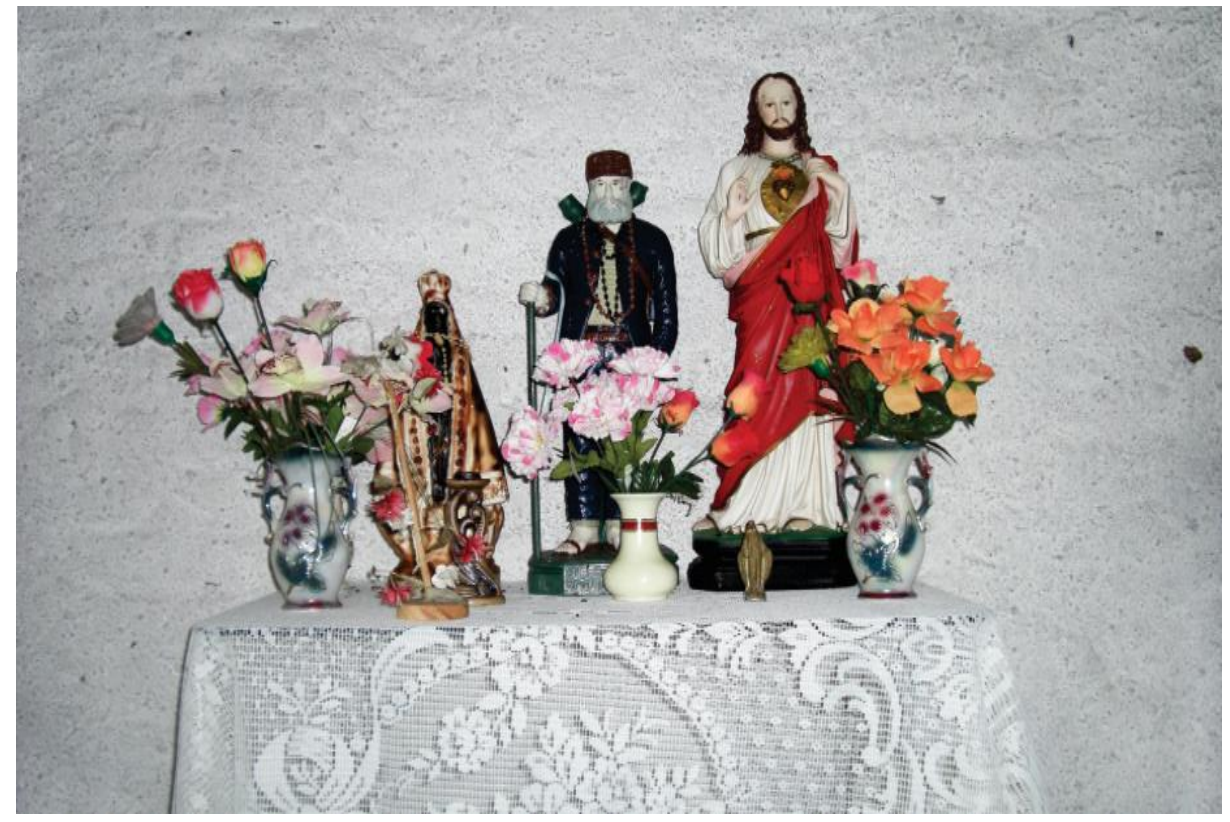

Figura 15: Altar também para São João Maria. Fonte: Claudia Ribeiro(2013); Criúva.

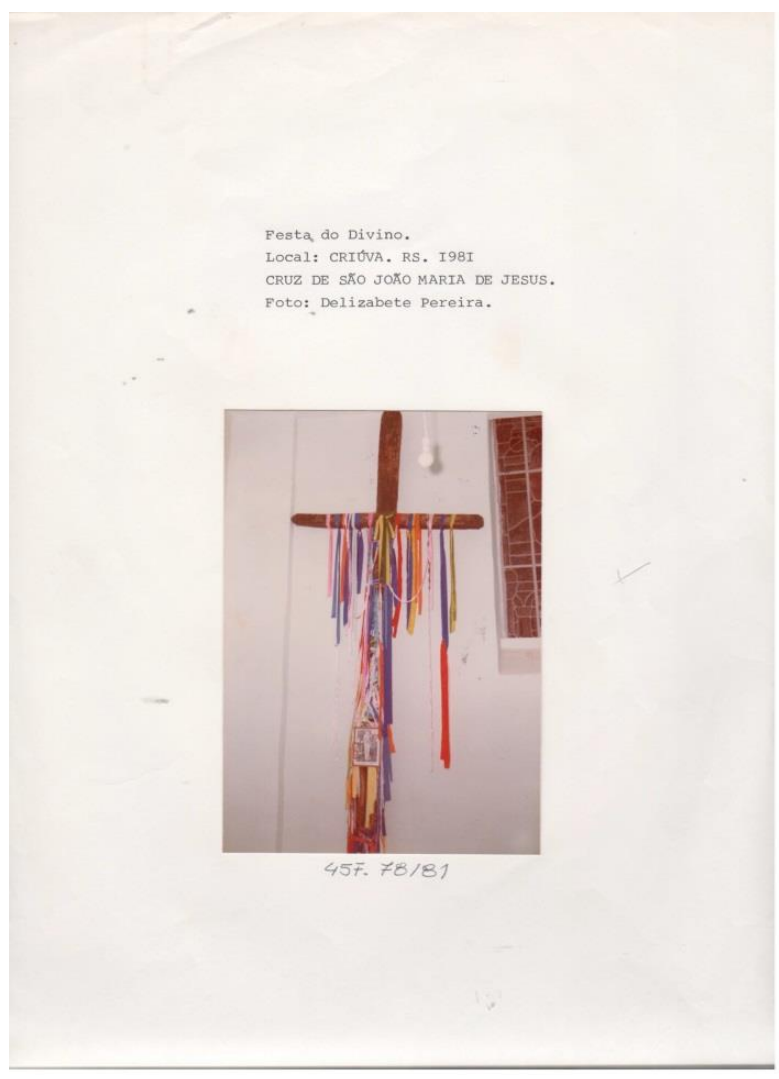

Figura 16: Cruz de São João Maria de Jesus.

Fonte: Delizabete Pereira, IGTF (1981); Criúva.

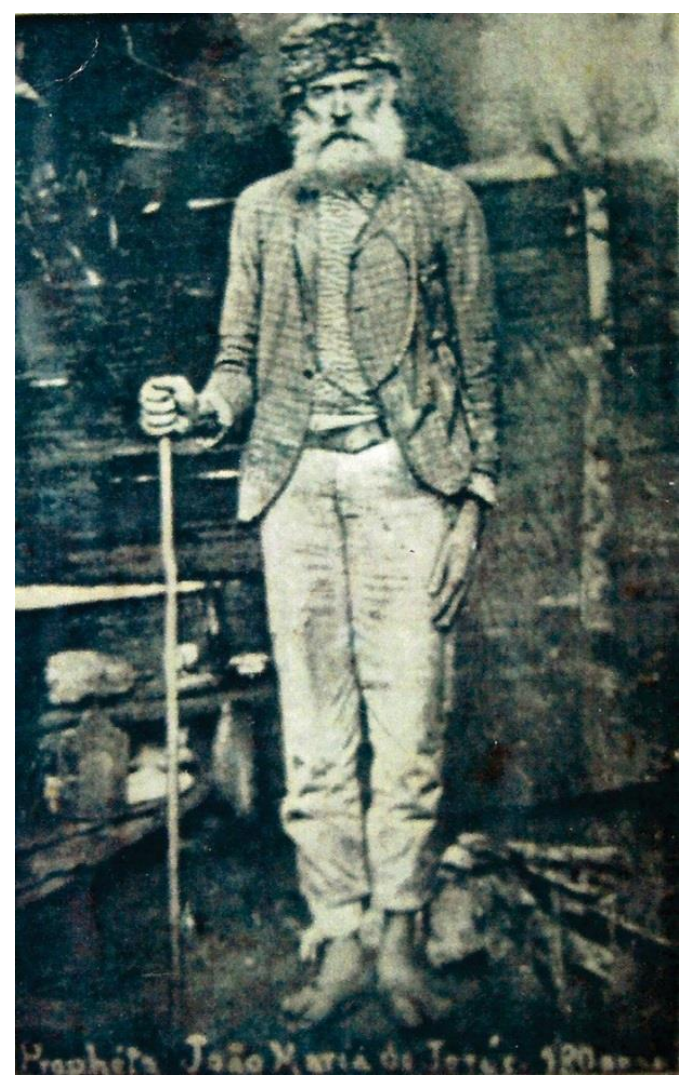

Figura 17: São João Maria "da Mata". Fonte: Claudia Ribeiro (2013); Criúva. 
Sobre ele conta Fátima, que mora no campo em Criúva, bem perto da capelinha dedicada a esse personagem (que fica na beira de um pequeno capão de mato, à margem de um pequeno regato), que "João Maria cruzou por aqui, meu avô contava, ficou cinco dias acampado ali perto do mato. Era um profeta, não era santo ainda para mim, como a gente dizia; veio de "lá para cá‘- dos lados da Mulada.". O amigo vizinho presente à conversa, na casa dos sessenta anos, adiciona que em Vacaria dizem que ele teria vindo de São José do Ouro.

A interlocutora justifica que, como no início havia pouca fotografia, por isso fizeram capelinha com a estátua. A capela que mostram "é novinha - a primeira era de madeirinha"; segundo ela, ainda do tempo do avô. Explica que "não queriam que rezasse missa, os padres custavam a aceitar - mas o padre Pedro (Rizzon) aceitou na hora".

Fátima expõe que aprendeu as benzeduras com uma irmã, que foi anotando tudo, "igual as do pai", que as "tinha pela cabeça". Por sua vez, o pai recebeu-as de seu pai - o avô de Fátima, a origem de suas memórias de João Maria. Hoje em dia, segundo ela, não vem muita gente pedir benzedura: "alguém ainda pede". Adiciona que não há muitas pessoas que nem ela, e que nem todas benzem para todas as coisas.

Luísa agrega outras visões. Tem seu dom desde criança, quando via e escutava um "casalzinho de pretos velhos de cativeiro, que eram escravos e que já morreram", que ela explica serem seus mestres: "eles me ensinaram tudo; eu tinha oito anos e ficava ali sozinha escutando, na escola, embaixo do pé de jasmim”. Ela é conhecida nos dois distritos e em suas vizinhanças, e passa, ainda hoje, mais de uma semana de uma propriedade a outra, nos campos, benzendo onde lhe pedem. Ela conta que benze para tudo - para inveja, para quebrante, para negócio, para livrar do perigo, para a saúde, para a pessoa que tem dor. Dor de muitas espécies: exemplifica que benze "as dores das pessoas", e também auxilia as mulheres que estão para ganhar filho - para desvirar uma criança ou deslindar um parto difícil. Ela explica que diz "as palavras poderosas", mas que em seguida não se lembra de mais nada. Também detalha que benze a criação com proteção de São Roque, em um exemplo de acordo aos ensinamentos que recebeu dos negros velhos. Luísa dessa maneira conta que "cada um tem a sua reza", e por isso reza muito para Nossa Senhora Aparecida e também para Nossa Senhora dos Nós - "a que desamarra tudo: primeiro Deus, depois todo o resto na vida". Mas também é devota de Nossa Senhora do Rosário, de Santa Maria da Boca do Monte e de São Jorge Guerreiro. Entre as várias instâncias espirituais a que recorre no seu procedimento, manifesta sua 
predileção pela padroeira de Cazuza Ferreira, que é "Nossa Senhora do Belo Horizonte" - santa que Arlindo também menciona, dizendo que é uma crença "belíssima". O seu fazer evidencia essa multiplicidade espiritual - misturada - da paisagem do lugar. E nele igualmente figura a especificidade de São João Maria - “é o da criação", e que, para ela, é sempre São João Maria “das Matas”. Como ela esmiúça, ele era aquele "que andava no mundo - um peregrino - quando começou o mundo, e ninguém sabia quem é que ele era". Explica que ele sempre pousava no mato, em um acampamento perto de água corrente, e que reagia de acordo com a recepção que tinha nas casas onde batia: “bênção ou 'assim' (sinal de repulsa) com a mão para a pessoa”. E outro aspecto remarcável que Fátima, Luísa e outras pessoas em Vila Seca e Criúva rememoram sobre esse peregrino é de que o seu acampamento sempre era assinalado por uma fogueira que não apagava nunca - nem sob as copiosas chuvas do inverno dos Campos de Cima da Serra.

A população negra, a qual, segundo Teixeira (2008: 125), em 1872 constituía 20\% do total de pessoas habitantes em São Francisco de Paula de Cima da Serra, ainda não tem sua inclusão plena na comunidade local, como esclarece Luísa: "aqui tem muito poucos (negros), e depois às vezes tem uns que são racistas - não gostam de negro". Ela reforça os anteriores achados que relatam a segregação existente nos bailes, que se encontra bem demarcada na paisagem do sistema agrário colonial: "antes a gente não dançava junto com os brancos; quando eu vim aqui era assim - aí era salão de tudo, mas os negros eles não queriam junto.”.

Os "mortos falam a esse respeito", uma vez que se fica sabendo que os negros falecidos estão enterrados em lugar distinto, com razão explicada claramente por Luísa: “eles estão no Capão da Erva - era o cemitério dos pobres, o daqui (próximo à igreja de Vila Seca) é o dos ricos". Além disso, seu relato demonstra que os maus-tratos em vários tipos e gradações, da época do "cativeiro", ainda não foram assimilados nesse lugar, fazendo com que ainda hoje não existam "misturas com os brancos" de uma forma mais corriqueira e integrada no lugar. Ela sublinha seu sentimento, enfatizando vigorosamente que "a devoção do Divino é dos morenos, os morenos ajudaram a fazer a igreja, faziam o churrasco de graça e a louvação". Dizendo que gosta muito, recita um pedaço da sua oração do Divino, muito próxima à que é recitada na louvação - rezas que não deixam de evocar o perpétuo movimento da paisagem: "Venha Espírito Santo, enchei o coração dos vossos fiéis e acendei neles o fogo do teu amor, que tudo será criado e tudo será vencido, e renovaremos a face da terra.". 
Outros relatos esclarecem melhor a abrangência espacial dessas segregações: até meados do século XX, existiam ainda bailes separados para morenos, brancos e "amarelos" na região como um todo ${ }^{11}$, e entende-se que isso ocorria mesmo associado às festas religiosas. E sobre os amarelos, encontra-se para eles melhor esclarecimento nesse recorrido pela história das várias etnias que fazem parte dessa paisagem, quando Arlindo refaz alguns traços quase que etéreos da presença indígena Kaingang na paisagem contemporânea desse lugar. Ele os enxerga nos traços fisionômicos de muitas pessoas, a começar pelos dele próprio: “[...] olha meu rosto, eu tenho rosto arredondado; o nosso olho puxado, a cor da pele - isso são os nossos antecedentes, de origem indígena [...]". Outro vestígio está nas palavras com que se referem aos antepassados. Esclarece que é muito comum, "na nossa região, daqui até Vacaria", as pessoas dizerem: "foi pegado a laço; a minha avó foi pegada a laço; a minha avó era bugra". Pela sua compreensão, isso quer dizer que a pessoa em questão é de origem indígena, e todas essas expressões, dessa forma, são expressões indicativas da miscigenação. Adicionalmente, enumera exemplos diretamente relacionados com os alimentos produzidos por esses primeiros agricultores, ainda presentes, senão no cotidiano, em sua memória. Fala do pixé - palavra de origem tupi-guarani, citada pelos seus pais como sendo a comida da família dos seus pais (avós paternos de Arlindo). Uma farinha de milho torrado, depois "pilado" (moído no pilão), que posteriormente se colocava no café, fazendo uma papa ou mingau. Também relata do plantio de três tipos de batatadoce e dois de aipim na beira do rio das Antas, e dos pães distintos do colonial de hoje: batidos, sovados, de milho e de centeio - "em um tempo em que isto não estava na moda".

Quando se busca entender a origem dos amarelos, Arlindo explica que vê sem dúvida nessa designação a componente étnica: mais identificada com a miscigenação indígena, mas também "com um pouco dos negros". Ele expõe que hoje não mais se usa essa expressão: de certa forma foi substituída pelo "quase gentílico", que usa a população da zona urbana de Caxias, para referir-se à população de seus distritos rurais situados nos Campos de Cima da Serra - o pelo duro.

Esse proceder, de acordo com o que se depreende ao longo do convívio propiciado pelo trabalho de campo, é levado com razoável leveza e bom humor pelos

\footnotetext{
${ }^{11}$ A pesquisa de campo registra esta situação em Vila Seca e Criúva, em Caxias do Sul, e igualmente encontra esse relato nos acompanhamentos realizados, por conta das "andanças dos festeiros", em Juá e Cazuza Ferreira, lindeiros distritos de São Francisco de Paula.
} 
habitantes do lugar. Nota-se que as pessoas do lugar relevam muitas vezes o emprego do termo, diz-se aqui, mas não de maneira ingênua - sabem muito bem do seu conteúdo não tão inocente, muitas vezes carregando conotações pejorativas.

A esse respeito, o dizer de Arlindo explicita com muita franqueza o discernimento das pessoas que moram no lugar. A expressão surge na região, e ele diz que se origina do fato de que "pelo-duro é uma raça de cavalos, se não estou equivocado". E daí, diz que "pelo-duro somos nós, de origem luso-brasileira - ou seja, todos com o sobrenome luso, pois não temos nenhuma cruza com a raça pura". Essa raça pura, ele esclarece, são "os novos que chegaram da Europa... se consideram a raça mais refinada, puros de raça, gente de raça fina.”.

E esse dizer contemporâneo do campo de Vila Seca e Criúva parece trazer ecos de acontecimentos da paisagem desse lugar em outros tempos. O que, para Augusto, não deixa dúvidas. Em seus quase 50 anos, esse morador urbano de Caxias, de suposta raça pura, mas com muitos amigos em Vila Seca e Criúva, entende que a utilização do termo traduz uma atitude preconceituosa com relação à região. Aqui se relaciona essa atitude contemporânea com o desconforto que os quadros de Pedro Weingärtner ${ }^{12}$ trouxeram a Porto Alegre, com gaúchos não tão bem vestidos - ou quem sabe, ponderase aqui, negros ou amarelos com roupas gaúchas. Ou em proximidade ao que diz Gomes (1966: 250) dos trabalhadores que constituíram as fazendas serranas: “[...] formando-se uma espécie de casta, os serranos [...] eram os afamados pés no chão, [...] que, com o tempo, se tornaram bons agricultores”. Rudi não quer mais sair do campo, mesmo tendo uma vida dura. Já saiu e voltou. Ressaltando não saber o que o futuro lhe reserva, manifesta uma certeza: não quer ir para Caxias. Não sabe explicar direito, mas sente-se melhor na capital. Esclarece que em Caxias sente olhares estranhos, em Porto Alegre, não. Exemplifica: “[...] entra numa lancheria para almoçar, puxa conversa com aquela pessoa e esta pessoa fica amigo, em Caxias já é diferente, puxa conversa e ficam te olhando [...]”. E seu sentimento é similar ao que Augusto afirma, em sua vivência na cidade, que "Caxias tem preconceito com o pessoal do campo; com tudo, exclui os não gringos.”.

\footnotetext{
${ }^{12}$ Ribeiro (2014) constrói uma possibilidade relativa a esse fato: várias de suas magníficas pinturas são fruto de uma muito provável passagem sua nesse lugar. Seria então nos Campos de Cima da Serra (e não na Campanha) que o pintor constrói a sua representação estética de gaúcho: muito próxima ao ainda hoje existente na realidade do lugar, e, pelo que os relatos do lugar trouxeram, provavelmente também em sua época.
} 


\section{A narrativa própria da paisagem do lugar}

Ao final da inserção etnográfica no ciclo da Festa do Divino Espírito Santo em Vila Seca, o recado recebido muitas vezes é que "A Festa do Pinhão é imperdível, para entender como é esta mistura de cultura e natureza que há por aqui.". Nesse contexto, um evento é decisivo para ampliar o trabalho previsto. Em Vila Seca vê-se uma foto antiga, nas mãos de organizadores da sua VI Festa do Pinhão - em campanha de coleta pelas casas da vila, para organizar uma exposição nessas festividades. Mostra-se esse registro na figura 18.

A festa do Pinhão é organizada por instância comunitária bastante diversa do que organiza a festa do Divino, ainda que existam pessoas que participam dos dois movimentos. Explicam vários relatos de que a decisão de criar essa nova festividade foi atribuída ao fato de essas pessoas identificarem que ficava "muita coisa fora da Festa do Divino", e também de seu desejo de organizar algo que fornecesse renda diretamente para a comunidade. O pinhão, que atravessa historicamente todos os sistemas agrários, foi o escolhido para ancorar a festa - que busca outra lógica de distribuição de renda. Sem a ingerência religiosa, mas utilizando os mesmos espaços comunitários - que são predominantemente controlados pela instância católica.

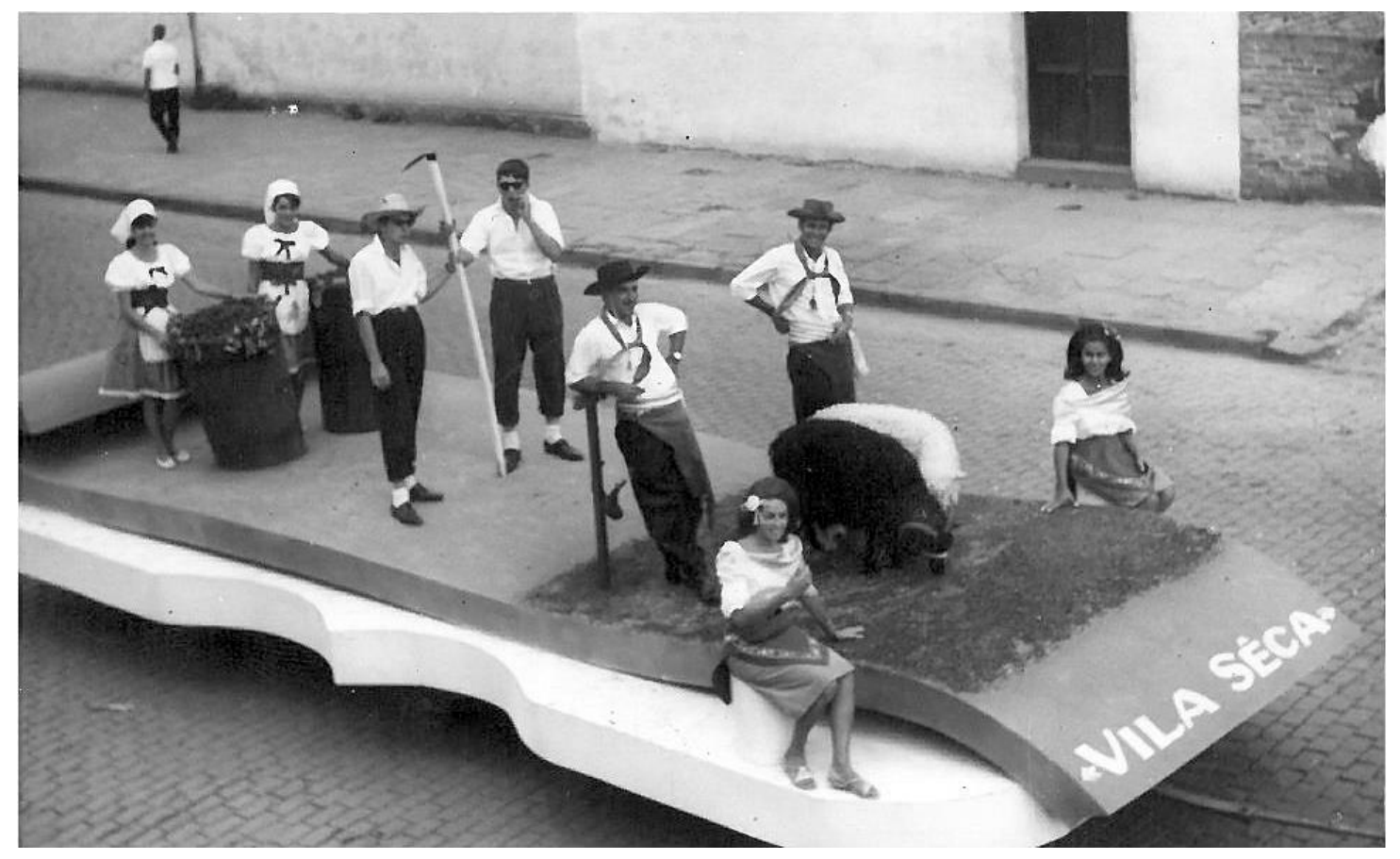

Figura 18: Vila Seca no desfile da Festa da Uva. Fonte: Elda Alves (s.d.), Vila Seca. 
Esse é um ponto sensível nas conversas, tanto em Criúva como em Vila Seca, desdobrado em múltiplos aspectos: da organização das festas, de quem faz exatamente quais tarefas, dos pagamentos existentes ou não para pessoas que trabalham nesses momentos, bem como do caso dos eventuais alugueis cobrados em espaços teoricamente públicos. Pois, pelo que se depreende, esses espaços foram oriundos de doações e trabalhos comunitários em várias outros momentos históricos. Enfim, o fato é que todos querem saber das contas finais de todas as festas - as religiosas católicas todas tem seu balanço final mostrado nas missas. Mas nem sempre as pessoas satisfazem-se, e há vários movimentos de profissionalização desses procedimentos contábeis. Nota-se um anseio por mais ingerência no recurso levantado pelo esforço de todos, ao mesmo tempo em que é evidenciado o desejo de potencializar e melhor dividir a dinâmica econômica suscitada pelas festas, de alegada relevante importância no lugar.

Assim é que, como última etapa do trabalho de campo, assiste-se ao desfile da Festa do Pinhão de 2013. E, nesse desfile, encontra-se também uma narrativa! Mas, nesse caso, composta e apresentada pelos moradores do lugar, compondo a sua versão do tramado narrativo que a jornada de pesquisa esforçou-se por captar da melhor forma possível. Se é que havia ainda alguma dúvida, nesse último ato da observação participante, encontrou-se por inteiro a prova que a paisagem existe em Vila Seca e Criúva. Esse dinâmico quadro de sua trajeção no lugar, que enfim compõe o coração da narrativa que resulta do trabalho, guarda total coerência com o carro alegórico da figura 18. É como se dele imergissem multiplicidades cenográficas da ruralidade vivida na paisagem do lugar. Como se escuta de um dos participantes de desfile de anos anteriores (em um dos vídeos que se assiste mais tarde, na pesquisa de acervo que se realiza): "não estamos representando ninguém - aqui somos nós mesmos".

Aqui não há como recompor por escrito a complexidade desse achado: ele fala por si próprio na narrativa imagética composta pelas figuras 19 a 39. E nesse conjunto, a cena que está na imagem 21 sela o entendimento de que o procedimento do fazer etnográfico foi adequado: num dos quadros do desfile, as crianças levam nas mãos desenhos, pinturas e fotos - suas próprias elaborações estéticas da paisagem do lugar. 


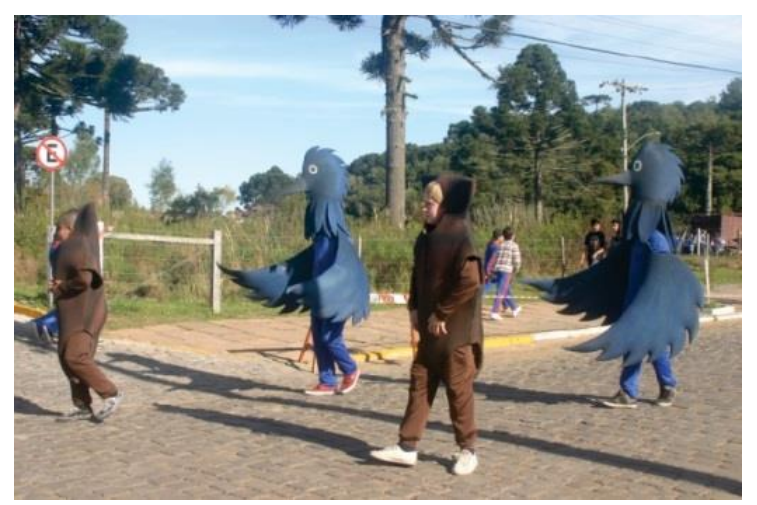

Figura 19: Gralhas e pinhões, no início do desfile.

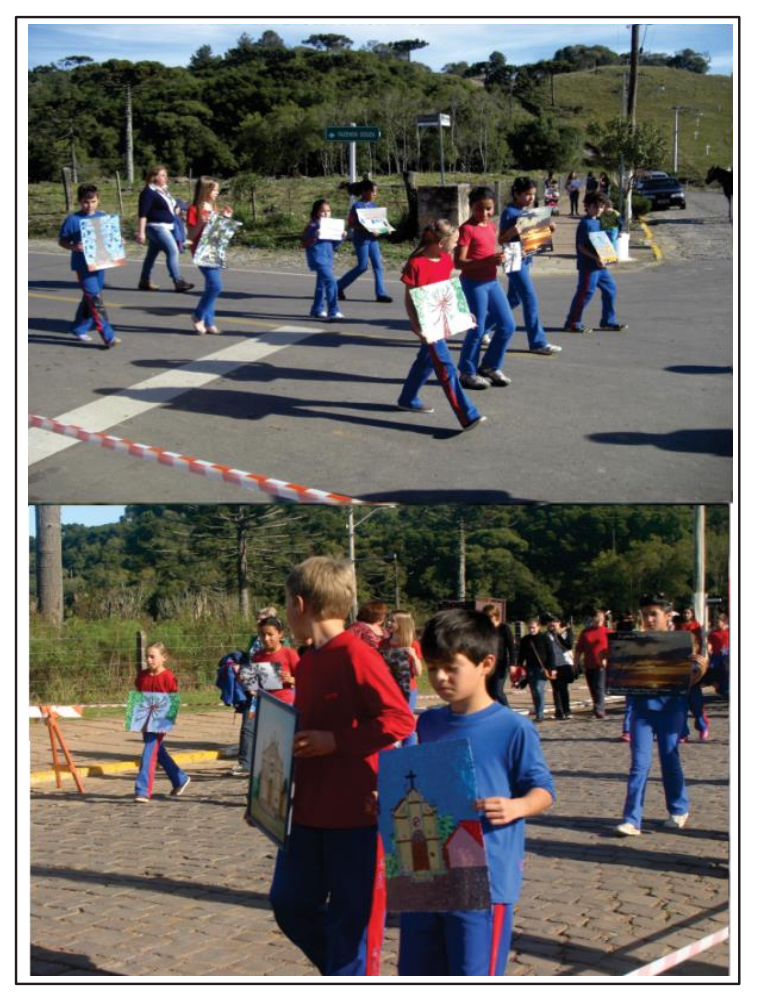

Figura 21: Mostrando a paisagem.

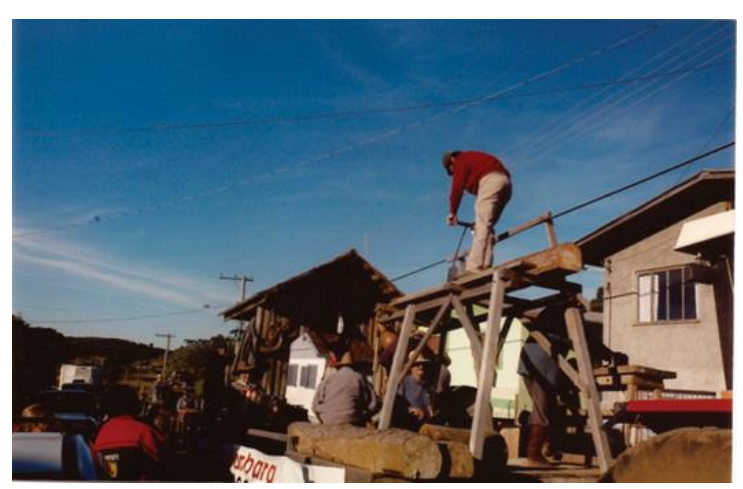

Figura 24: Serrando as toras do mato.

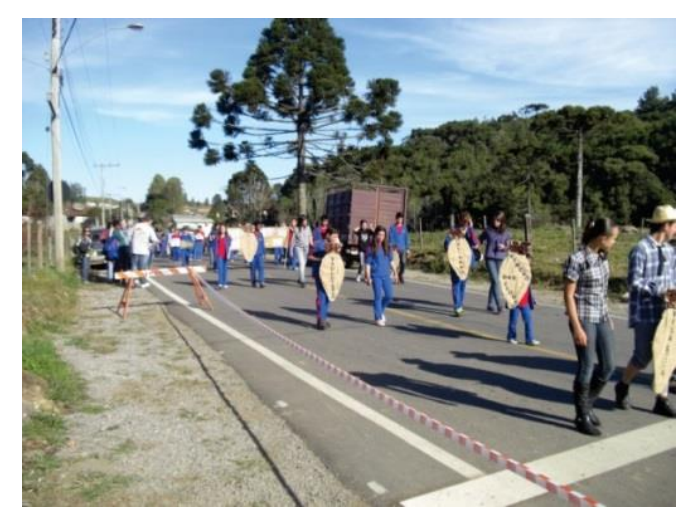

Figura 20: Os nomes do lugar.

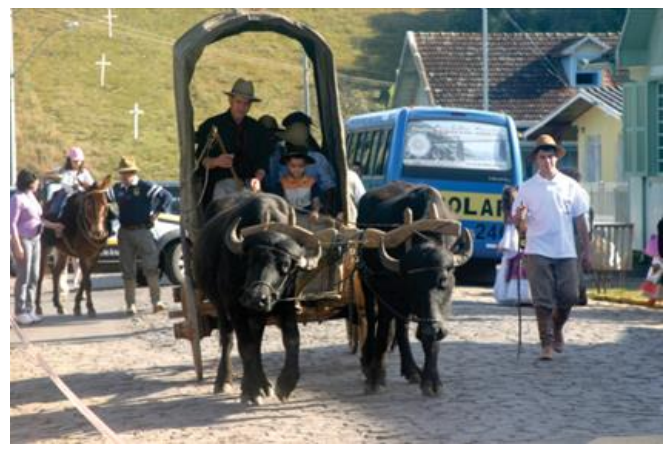

Figura 22: A chegada dos sesmeiros.

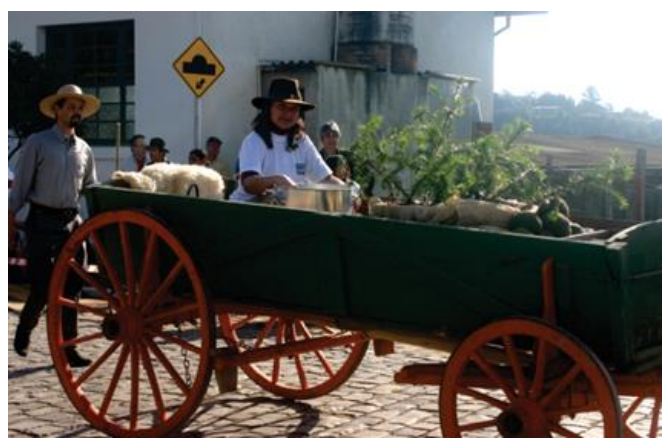

Figura 23: O povo das araucárias?

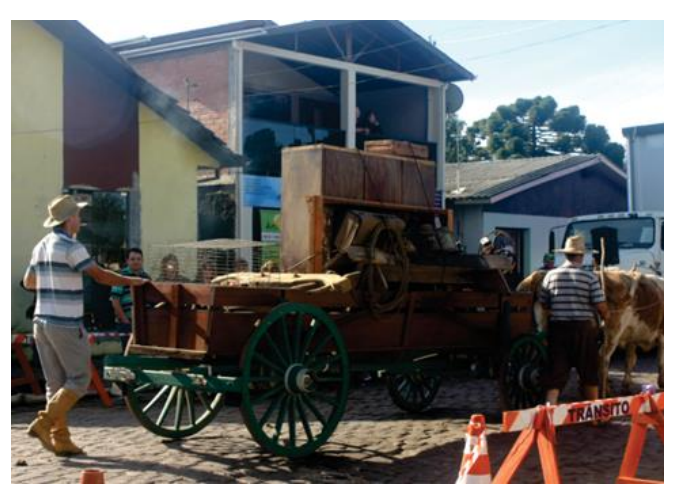

Figura 25: Vai-e-vem entre campo e colônia.

Fontes: 19, 20, 21, 22, 23 e 25, Claudia Ribeiro (2013); 24, Raul Fonseca (2010); Vila Seca. 


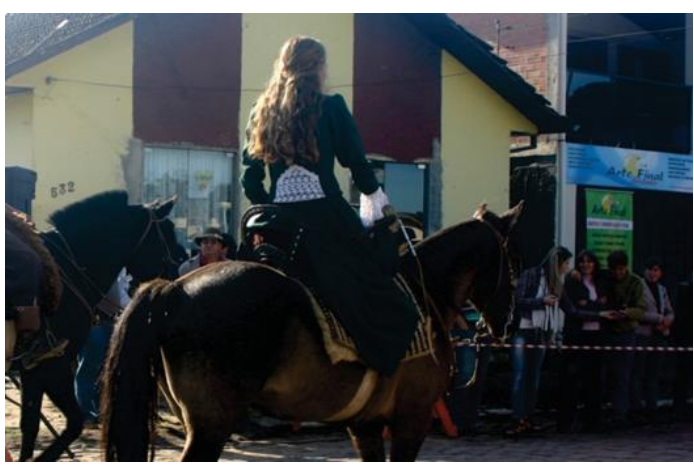

Figura 26: Campo de roupa bonita.

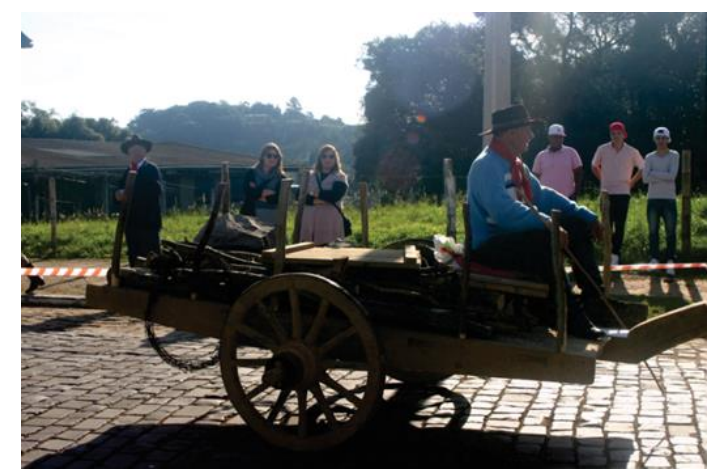

Figura 28: Fazendo os limites das terras.

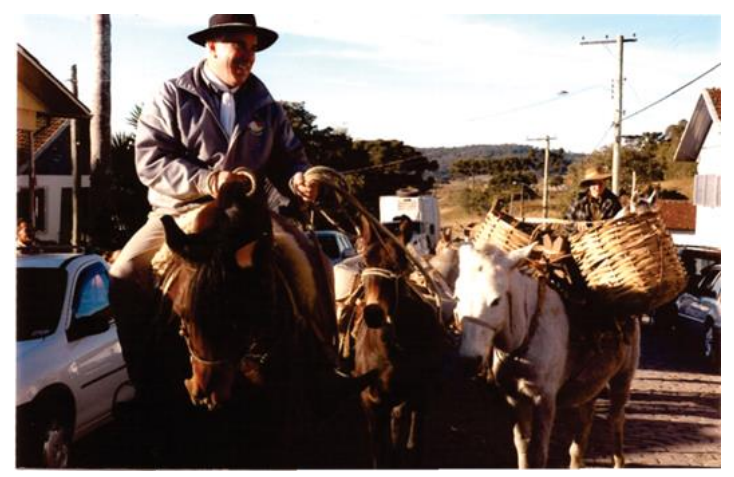

Figura 27: Muitas viagens do tropeiro e seus cargueiros.

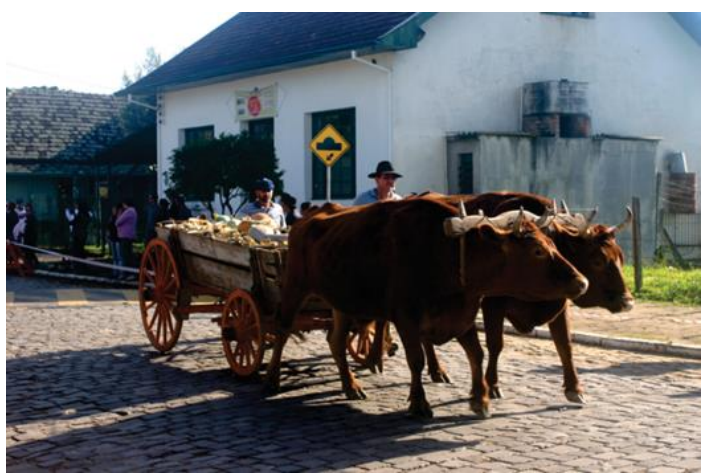

Figura 29: Abóboras e pasto vêm da colônia.

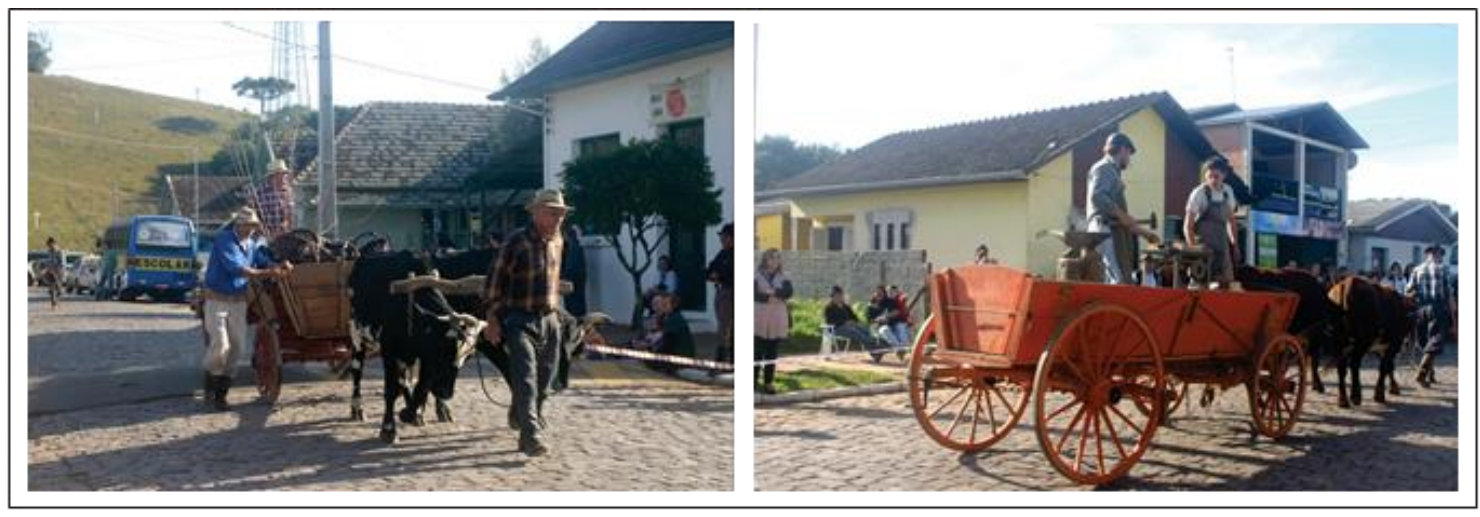

Figura 30: Cesteiro e ferreiro têm trabalho no lugar.

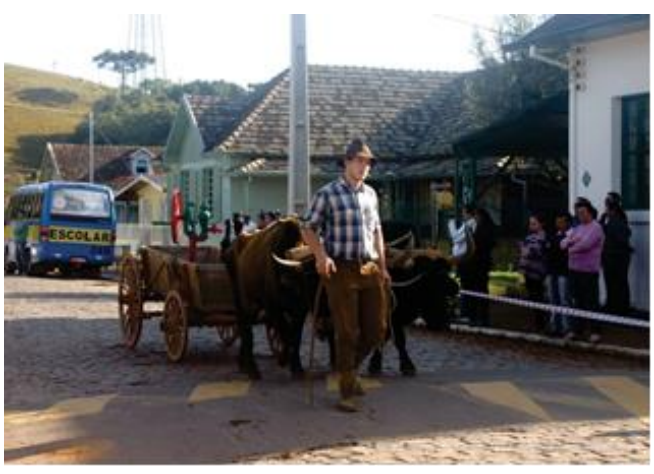

Figura 31: Mostrando o carneiro hidráulico.

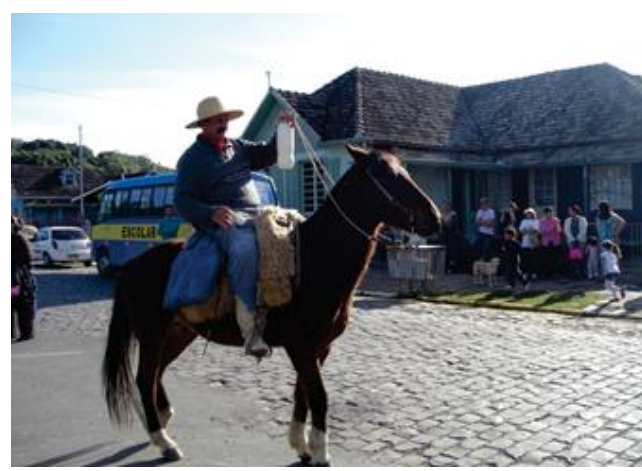

Figura 32: Leite na porta de casa.

Fontes: 26, 28, 29, 30, 31 e 32, Claudia Ribeiro (2013); 27, Raul Fonseca (2010); Vila Seca. 


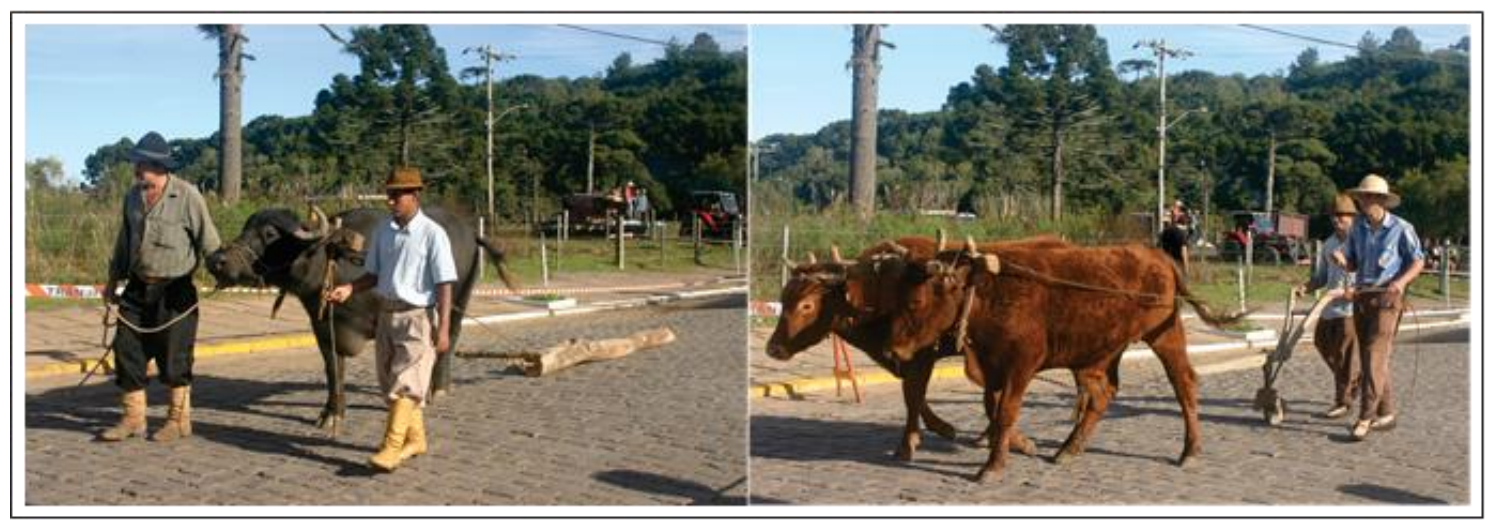

Figura 33: Trabalhando a terra para o plantio.

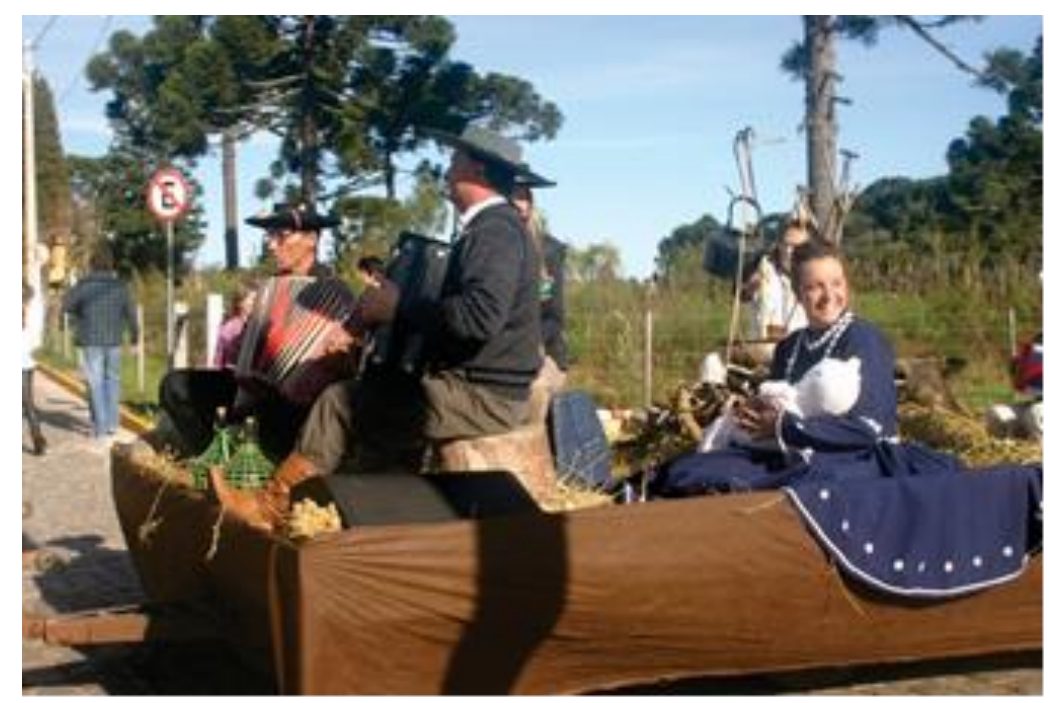

Figura 34: Indo fazer serenata.

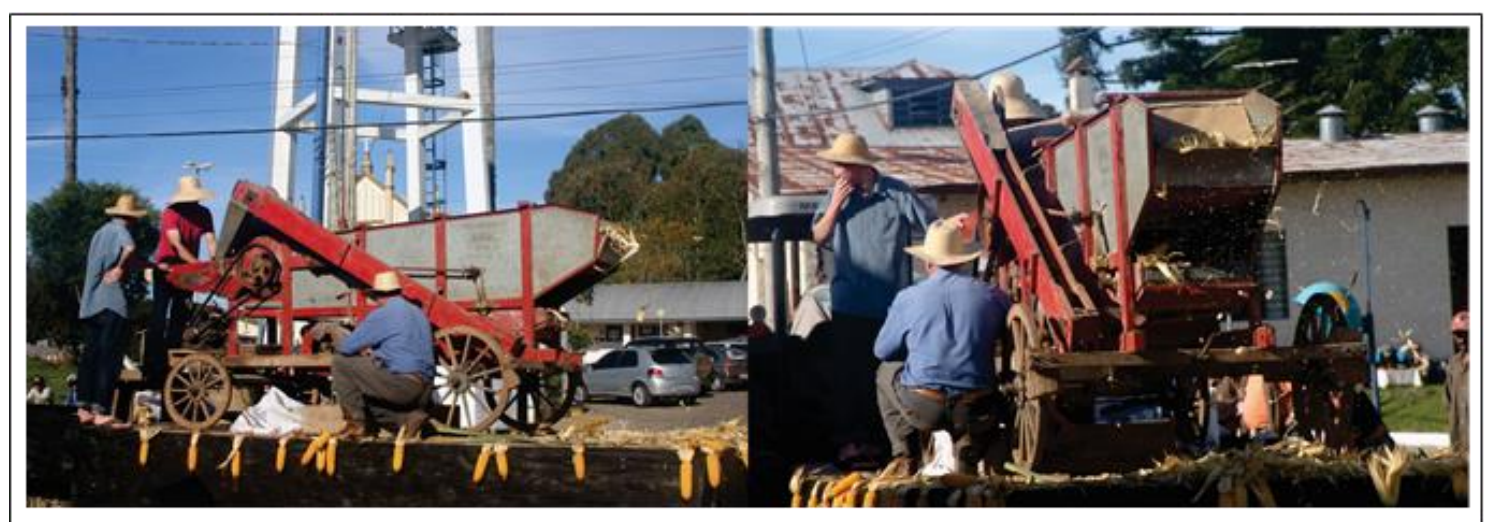

Figura 35: Trilhando o milho.

Fontes: 33 a 35, Claudia Ribeiro (2013); Vila Seca. 

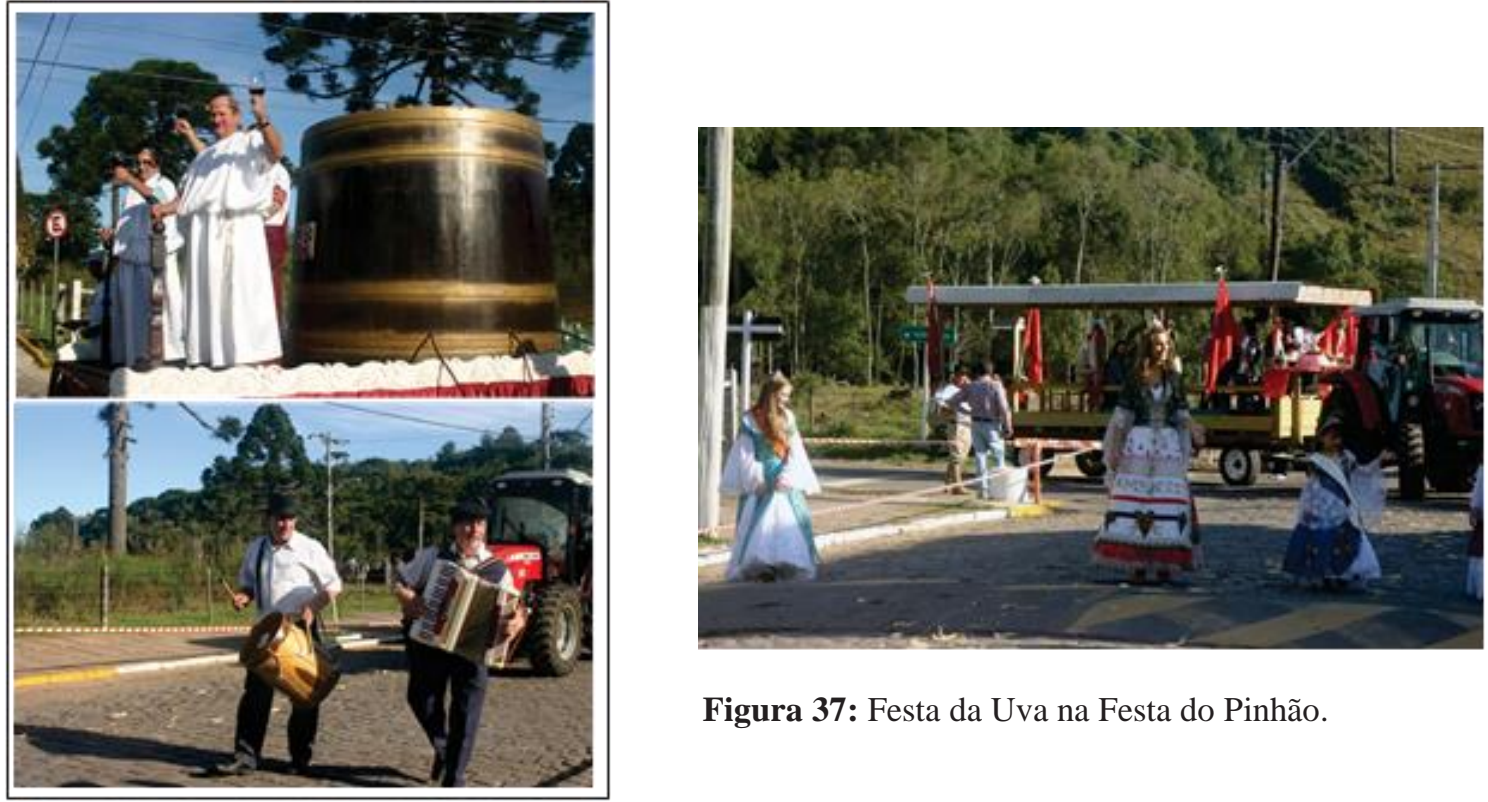

Figura 37: Festa da Uva na Festa do Pinhão.

Figura 36: Festa para o vinho novo.

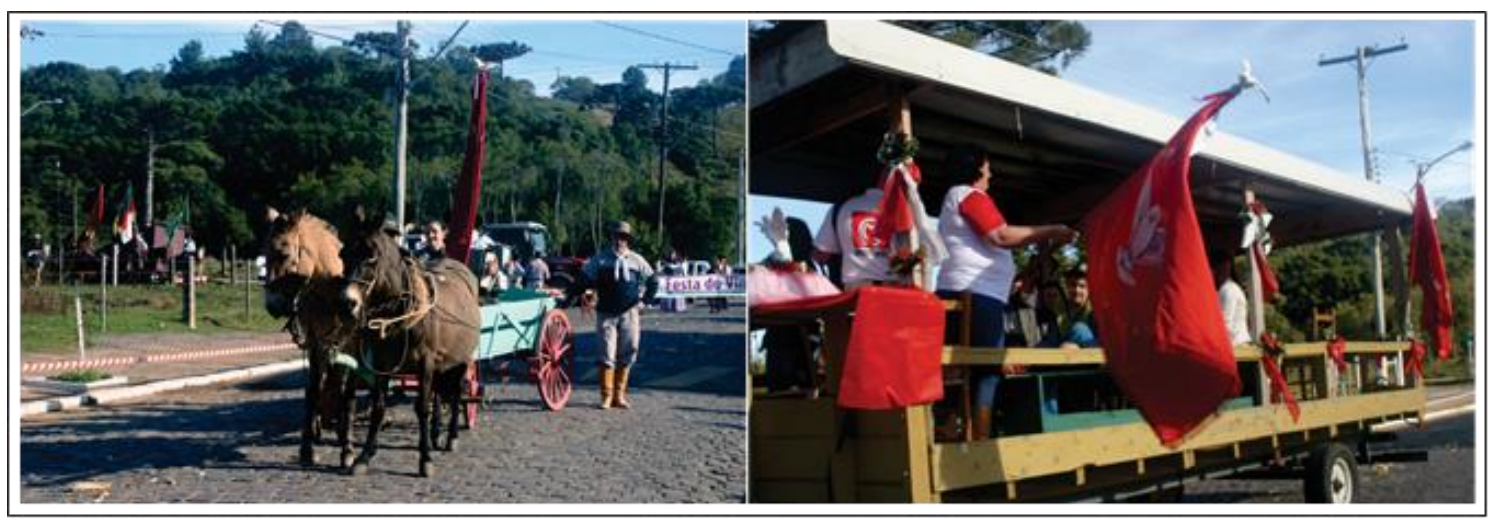

Figura 38: O Divino Espírito Santo da paisagem do lugar.

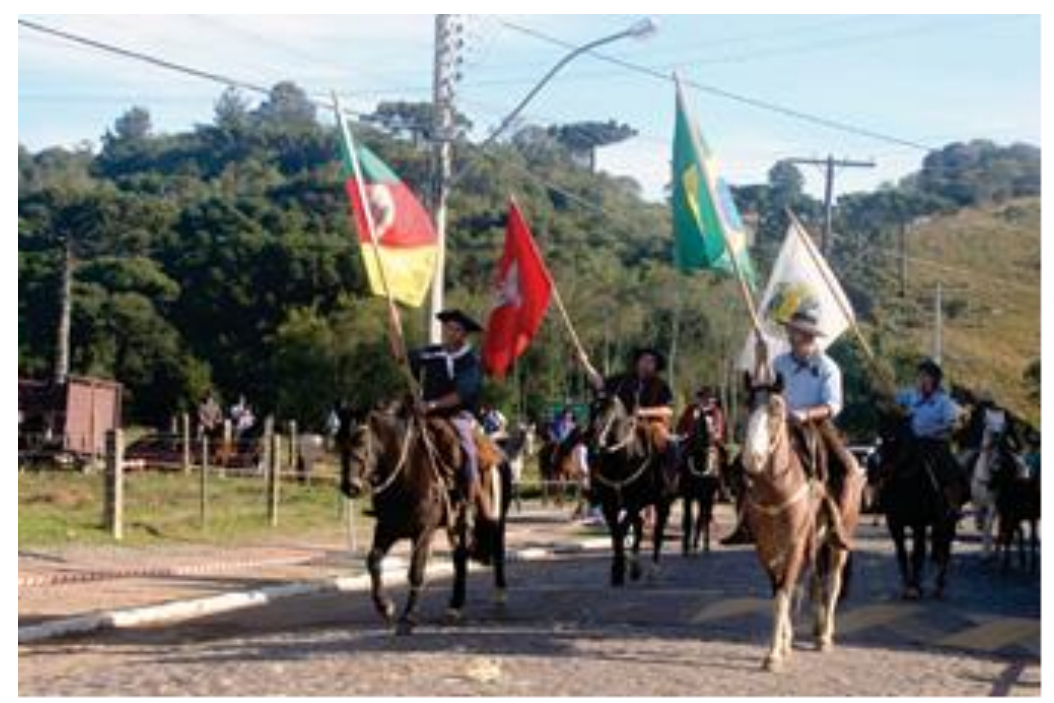

Figura 39: Todas as bandeiras de Vila Seca.

Fontes: 36 a 39, Claudia Ribeiro, (2013); Vila Seca.

Iluminuras, Porto Alegre, v. 16, n. 40, p. 260-300, ago/dez, 2015. 


\section{Redimensionando o horizonte do ato etnográfico}

Realiza-se um balanço dos achados etnográficos que a narrativa da paisagem do lugar esforça-se por criticamente reconstituir. Ribeiro, Dal Forno e Miguel (2015) mostram que a paisagem é um bem comum no lugar, no sentido de Hess e Ostrom (2007) e Leite (2012): ela é um recurso (cultural e mutável), compartilhado por pessoas e, portanto, sujeita a dilemas sociais. Esse entendimento quer dizer também que esse espontâneo proceder de conservação da paisagem não tem garantias, pois corresponde a um território em disputa, onde estão em jogo outros sentimentos e desejos - mormente o atendimento de funcionalidades urbanas -, além dos oriundos desses habitantes do lugar, majoritariamente agricultores. A ruralidade do lugar tem raízes fortes em suas práticas agrícolas, que, neste momento, diz-se que podem seguramente ser alojadas em gradações de campesinidade, no entendimento de Woortmann (1990). Sua agricultura de características familiares situa-se na ruralidade contemporânea, em um quadro de complexificação ligado às suas atividades produtivas, integrando diversidades outras além das agrícolas - coexistem nessa paisagem agricultores e extrativistas, artesãos e artífices, promotores de turismo rural e prestadores de serviços, entre outros tantos meios de vida que poderiam ser arrolados na contemporânea cena brasileira. Além disso, existem igualmente as atividades de membros da família que podem ser desenvolvidas igualmente no meio urbano não muito distante (Diegues et al., 2000; Wanderley, 2001; Favareto; Wanderley, 2013).

A densidade da narrativa de paisagem em Ribeiro (2014) permite visualizar possibilidades emancipatórias inseridas na discussão das possibilidades de sua conservação: tanto pelas alteridades internas a essa paisagem, como pelas demandas de recursos naturais e ordenamentos ambientais técnico-científicos oriundos da interface com uma grande cidade. Dessa forma, ilumina dimensões outras do relacionamento desses seres humanos com o seu meio, em complementaridade à autorreprodução inerente a uma dimensão somente ambiental. Em outras palavras, a partir disso evidencia-se que o seu modo de viver contempla dimensões de fruição desse meio, o que sobremaneira enriquece o desejo de continuidade também identificado. A sobrevivência não é qualquer uma, mas aquela que contém as riquezas específicas da paisagem do lugar, em toda a sua diversidade e delicados aspectos de alteridade e associados desejos de emancipação. Ou seja, existem vozes subalternas a serem escutadas. 
Gutwirth (2001), Oliveira (2006) e Peirano (2014) situam o ato etnográfico como sendo uma experiência compreensiva e não simplesmente metódica. A experiência antropológica é, antes de tudo, uma opção teórica. Se Oliveira (2006) detalha a constituição de um sujeito epistêmico antes da partida do etnógrafo para o terreno empírico de sua investigação, Carvalho (2001: 109) o vê contemporaneamente como transitando por "gêneros disciplinares difusos ou imprecisos", com o campo cultural podendo ser apreendido em renovadas incursões. Cita as produções em Antropologia Visual, Religião, Etnopoética e Etnomusicologia como exemplos para ilustrar maneiras de "descolonizar paisagens mentais", em metamorfoses do fazer etnográfico para lidar com essa relativamente nova situação de atuação. O autor reconhece que essa nova situação é conformada por variadas correntes e compartimentos disciplinares e suas recombinações, no entanto, apontando para o campo póscolonial como uma alternativa sensível nessa direção de reconfiguração do ofício etnográfico. Ressalta ele, porém, que esse fazer inscreve-se em inquietações relacionadas ao papel que as ciências sociais bem desempenham no contexto do projeto moderno, como um mecanismo produtor de alteridades. Nesse sentido, a preocupação de Carvalho (2001: 116; 138; 140) quando sugere um trabalho etnográfico com sensibilidade distinta do que denomina ser a desconstrução histórica proposta pela estratégia pós-colonial - antecipa os questionamentos de Catherine Walsh (2007) em torno da produção de conhecimento nas ciências sociais e da busca de novos lugares de pensamento.

Carvalho propõe, em alternativa às revisões literárias de obras consagradas, uma pesquisa engajada, justamente onde se avalie criticamente o fazer etnográfico: é preciso saber “quem estuda o quê sobre quem". Contudo, enfatiza a dificuldade de manter duas lealdades: é preciso escolher entre a metrópole e a subalternidade. Por meio da inscrição das obras de nossas populações, ele antevê a produção de gramáticas a serem utilizadas "num caminho emancipatório das comunidades postas à margem dos recursos do Estado ao qual estão legalmente atadas". Sem espaço aqui para aprofundar a riqueza de sua construção a partir dos principais autores pós-coloniais, retém-se uma de suas sugestões: a da difícil tarefa de viabilizar a fala do subalterno, nos termos de Gayatri Spivak (1993). A partir da literatura oral, o autor estimula que se coloque o texto periférico como tema inicial, por intermédio da escuta e registro de "vozes ainda não inscritas no cânone", compondo uma obra a partir do trabalho de recomposição e aglutinação desses fragmentos. Já Walsh (2007) nisso inclui possíveis externalidades aos convencionais circuitos acadêmicos, e igualmente os procedimentos que tensionem as teorias eurocêntricas. $\mathrm{O}$ alerta principal da autora é o de manter presente a 
delicadeza de condução dessa missão, com evidentes riscos de folclorizar o sujeito ou de municiar estratégias para sua manipulação e controle político.

Tendo em vista o já manifestado interesse da pesquisa pelo entendimento das lutas ambientais dos sujeitos do campo empírico, mediante o aprofundamento de suas narrativas de trajeção de paisagem, caracteriza-se o contexto espaço-temporal do dilema social bem identificado nessa situação. Justo o drama social - como intriga de fundo da vida humana em encruzilhada espaço-temporal - é relacionado por Rocha e Eckert $(2013: 30,31,32)$ à fenomenologia dos estudos de memória em contexto moderno-ocidental, entendida segundo a obra de Paul Ricœur. A cultura, por sua vez, ao mesmo tempo em que sedia "a esperança essencial" da humanidade, depende visceralmente do processo de identificação do ser humano com algo, segundo Durand (1980: 470, apud Rocha e Eckert, 2013: 31, 32). Também representa, para as autoras, "a sua luta contra a dissolução no tempo", e, por isso, intrinsecamente ligada à memória. Esclarecem ainda elas que, para Bachelard (1988), a memória acontece a partir "de decisões do sujeito humano no tempo".

Logo, as hesitações fazem parte do fenômeno da duração, cujo desejo não é o bergsoniano "durar no tempo", mas o "permanecer no espaço", compreendendo uma dialética que o ser constrói, entre a matéria e a vida - e não uma simples oposição de sujeito e objeto. A matéria é estável ritmicamente e não "congelada no espaço"; como tal, é vista como atingindo a duração somente quando atinge algum tipo de equilíbrio - um acordo temporal (a duração) em um tempo que vibra (hesita), lacunarmente. Daí depreende-se viável utilizar a pergunta das autoras para pensar a conservação ambiental: "O que permanece? O que é que dura?". Elas mesmas dão uma indicação dessa resposta, quando dizem que o estudioso da memória deve recusar "a ideia ingênua da plenitude do mundo das coisas, posto que a ideia da continuidade do tempo não é um dado em si mesmo, mas uma obra”. Em suma, o que dura é uma obra, ou "apenas aquilo que tem razões para recomeçar" (Rocha; Eckert, 2000: 9-13).

Nesse contexto, a partir da invocação de Simmel (1981: 235) por Rocha e Eckert (2013: 145), pensa-se sobre a difícil apropriação de sentido do olhar, que deve, segundo o sociólogo, necessariamente passar pelo compartilhamento de imagem. A partir disso, entende-se um pouco melhor a pregressa e intensa utilização de recursos imagéticos em Ribeiro (2014) - não parece mesmo haver maneira de bem restituir a paisagem que se busca compreender sem passar por esse recurso. E, adicionalmente, compreende-se que o que se está a fazer poderia ser entendido como uma recomposição da memória dos sujeitos, dentre tantas possíveis, por intermédio do acesso, seleção e reconfiguração dos vários instantes 
guardados. Em intenso enraizamento de conteúdo audiovisual, a ideia de conservação, cara à temática proposta, é aproximada à questão da memória.

Essa reflexão parece apontar igualmente um caminho mais satisfatório para outro aspecto delicado da conduta etnográfica. No caso já em marcha, testemunha-se que não há como o pesquisador-autor evitar o questionamento do nativo, que são as pessoas do lugar, alvos dessa curiosidade que é apenas cientificamente justificada. Esses seres humanos, muito mais do que auxiliar o desvelar proposto, colocam os seus questionamentos ao processo como um todo e também as suas próprias teorias como respostas às perguntas que acolhem. Como diz Oliveira (1988: 69), a partir do questionamento da legitimidade de atuação dessa “autoridade então inconteste", ocorrem mudanças no horizonte etnográfico - aparecendo algum tipo de "saber negociado", resultado de "relações dialógicas [...] onde pesquisador e pesquisado articulam ou confrontam seus respectivos horizontes". E, dessa forma, o texto que se procura elaborar como resultante final desse confronto (termo quem sabe melhor do que encontro) não pode estar mais submetido a um autor todo soberano, único intérprete de seus dados, mas deve integrar de alguma maneira o saber do Outro e, se possível, ser polifônico, onde as vozes dos Outros tenham a chance de serem ouvidas.

E, nesse exato ponto, a utilização de imagens abre portas singulares de uma mútua e reflexiva construção de conhecimento. É necessário ver que esse potencialmente profícuo diálogo é de primeiro, guiado pelo interesse do pesquisador, que, por sua vez, é epistemologicamente conduzido (o que não é pouco) - uma vez que orientado pelas teorias escolhidas. Mas talvez sejam os habitantes e seus saberes que guiam a vida na paisagem do lugar, que podem expor a chave para a duração dessa paisagem: a luta da memória contra o tempo e seus desarranjos espaciais. 


\section{Considerações Finais}

Repensa-se o singular evento ocorrido na prática etnográfica que aqui se retraça. Ao escutarem-se os sutis recados sobre necessários olhares para o que ficava de fora da Festa do Divino Espírito Santo, a paisagem consegue ficar mais nítida, em uma visão mais próxima de seu conjunto de singularidades. É justamente no rastro da aceitação desse convite que se visualiza um caminho de aprofundamento desse ato etnográfico, para descobrir as possibilidades de duração desta paisagem no viver cotidiano de seus habitantes.

O campo de estudo empírico continua sediado no lugar Criúva e Vila Seca, cuja abrangência territorial deverá ser mais bem entendida. Há clareza de que o que pode ser objetivado é fruto de uma interpretação de algo distinto de articulações de sujeitos e objetos continua-se perseguindo a inteireza de uma paisagem. A geometria epistêmica que conforma essa busca é comprometida com possibilidades descolonizantes: como diz Anjos (2014: 30), apostando na "renovação de paradigmas a partir de saberes locais", em que o horizonte político reside na prospecção de "modalidades ainda não inteiramente explicitadas de pósdesenvolvimento, do não capitalismo e de alter-natureza localizáveis na periferia do capitalismo globalizado", que poderiam localmente transformarem-se em bases "de redes alternativas mais humano-ecológicas do mundo". Diz-se aqui, utilizando-se expressão do autor, que o que se busca é uma "outra natureza-cultura" que pode estar contida na singular paisagem desse lugar.

Uma das boas pistas nesse caminho é aprofundar o conhecimento das razões e sentimentos que fazem João Maria das Matas ser tão querido no lugar. Cogita-se que esse humano profeta, profundamente entranhado na natureza do lugar, desempenhe os dois papéis que Karlsburg (2014) distingue. Pois ele continua suprindo as necessidades espirituais das pessoas que ficam "desconfiadas" para ir à igreja - talvez porque em algum momento em suas histórias de vida tenham assumido não serem tão puras - ou brancas. E em igual intensidade, o monge constitui um canal seguro para expressar as bênçãos ou maldições para determinadas atitudes no lugar, quiçá contendo as utópicas esperanças de que essa paisagem possa ser, como diz Don Mitchell (2003: 793), "a terra de sonho" de uma sociedade mais simétrica.

Tentativamente articulam-se novas entradas nesse campo de ação etnográfico, em continuidade da pesquisa em contexto multidisciplinar. A dificuldade principal antecipada continua centrada na utópica busca da completude do Outro. Mesmo sabendo-se do cuidado e sutileza do tratamento da questão subalterna, algumas importantes inquietações ficam 
registradas para melhor exploração. Mais do que tudo, de conseguir conduzir esse encontro em caminho seguramente distante da estigmatização. Além disso, da necessidade do permanente zelo do pesquisador por sua lealdade a um discurso único. No caso, a lealdade reside na intenção de contribuição para a reconstituição da voz subalterna: a da paisagem do lugar. Supõe-se que esses habitantes do lugar, agricultores de práticas familiares em sua maioria, tenham projetos de vida, cujo desvelar possa contribuir à sua já iniciada e própria construção de hipertextual gramática - para o reforço de suas atitudes descolonizantes ao quadro de ameaças que é também construído pelas necessidades ambientais impostas pelo mundo do desenvolvimento.

\section{Referências}

ANJOS, J. C. G. Espaços epistêmicos das ciências sociais na contemporaniedade. In: CONTERATO, M.; RADOMSKY, G. F. W., SCHNEIDER, S. (Org.). Pesquisa em desenvolvimento rural: aportes teóricos e proposições metodológicas. Porto Alegre: UFRGS, 2014.

BACHELAR, G. A dialética da duração. São Paulo: Editora Ática, 1988.

BERQUE, A. A ecúmena: medida terrestre do Homem, medida humana da Terra. Para uma problemática do mundo ambiente. In: SERRÃO, A. V. (Org.). Filosofia da Paisagem. Uma Antologia. Lisboa: Centro de Filosofia da Universidade de Lisboa, 2011.

BRANDÃO, C. R. O Divino, o Santo e a Senhora. Rio de Janeiro: Fundação Nacional de ArteFUNARTE, 1978.

CARDOSO DE OLIVEIRA, R. Sobre o pensamento antropológico. Rio de Janeiro/ Brasília: Tempo Brasileiro/ CNPq, 1988.

. O trabalho do antropólogo. Brasília: Paralelo 15 e UNESP, 2006.

CARVALHO, J. J. O olhar etnográfico e a voz subalterna. Horizontes Antropológicos, v. 7. 7, n. 15: p. 107-147. Porto Alegre. UFRGS, 2001.

DIEGUES, A. C. S. et al. Saberes Tradicionais e Biodiversidade no Brasil. Brasília, 2000. Disponível em: < http://www.usp.br/nupaub/Saberes_PDF.pdf, em 30/10/2011 >.

DURAND, G. As estruturas antropológicas do imaginário. Lisboa: Presença, 1980.

ESCOBAR, A. O lugar da natureza e a natureza do lugar: globalização ou pósdesenvolvimento? In: LANDER, E. O. (Org.). A colonialidade do saber: eurocentrismo e ciencias sociais. Perspectiva latino-americanas. Ciudad Autónoma de Buenos Aires: CLACSO, Consejo Latinoamericano de Ciencias Sociales, p.133-138, 2005. (Colección Sur Sur).

FACCHIN, P. R. et al. Projeto de Preservação das Áreas de Produção de Água-Distritos de Vila Seca e Criúva. Caxias do Sul: Prefeitura Municipal de Caxias do Sul 2007.

FAVARETO, A. S.; WANDERLEY, M. D. N. B. A singularidade do rural brasileiro: implicações para tipologias territoriais e elaboração de políticas públicas. In: MIRANDA, C. E. S., H. (Org.). Concepções da Ruralidade Contemporânea: as singularidades brasileiras. Brasília: Instituto Interamericano de Cooperação Agrícola, 2013, p. 413-472.

GOMES, A. M. Fundação e Evolução das Estâncias Serranas. Cruz Alta: Livraria Liderança, 1966.

GUTWIRTH, J. A. A etnologia, ciência ou literatura ? Horizontes Antropológicos, v. 7, n. 16: p. 223-239. Porto Alegre: UFRGS, 2001.

HESS, C.; OSTROM, E. Introduction: An Overview of the Knowledge Commons. In: HESS, C. e OSTROM, E. (Org.). Understanding Knowledge as a Commons. From Theory to Practice. Cambridge, Massachusetts; London, England: The MIT Press, 2007. 
IBGE.Instituto Brasileiro de Geografia e Estatística. Censo Demográfico. Tabela 130. Sistema IBGE de Recuperação Automática - SIDRA, 2010a. Disponível em:

$<$ http://www.sidra.ibge.gov.br/bda/tabela/protabl.asp?c=1301\&z=t\&o=4\&i=P>. Acesso em: 21 jun. 2012>.

IBGE.Instituto Brasileiro de Geografia e Estatística. Censo Demográfico. Tabela 1378. Sistema IBGE de Recuperação Automática - SIDRA, 2010b. Disponível em:

$<$ http://www.sidra.ibge.gov.br/bda/tabela/protabl.asp?c=1378\&z=cd\&o=7\&i=P>. Acesso em: 21 jun. 2012 .

KARSBURG, A. O. A trajetória de um eremita peregrino na América Católica do Século XX. Debates do NER, ano 15, n 25: p 17 a 71. Monge João Maria, Devoção e Pessoa. Porto Alegre, UFRGS, 2014.

LEITE, M. A. F. P. A Contribuição da Arquitetura Paisagística para a Discussão da Paisagem Cultural. Texto recebido por intermédio de comunicado pessoal (mensagem eletrônica): 2. Colóquio Ibero-americano Paisagem Cultural, Patrimônio e Projeto, Belo Horizonte, 2012.

LIPPARD, L. R. The Lure of the Local. Senses of Place in a Multicentered Society. New York: The New Press, 1997.

MARTINS, J. S. Capitalismo e Tradicionalismo. Estudos Sobre as Contradições da Sociedade Agrária no Brasil. São Paulo: Livraria Pioneira Editora, 1975.

MASSEY, D. Um sentido global do lugar. In: ARANTES, A. A. (Org.). O Espaço da Diferença. Campinas: Papirus, 2000, p. 177-185.

MITCHELL, D. The lure of the local: landscape studies at the end of a troubled century. Progress in Human Geography, v. 25, n. 2: p. 269-281, 2001.

Cultural landscapes: just landscapes or landscapes of justice? Progress in Human Geography, v. 27, n. 3: p. 787-796, 2003.

PAIXÃO CORTES, J. C. D. Folias do Divino. Porto Alegre: PROLETRA, 1983a. . Folk festo e tradições gaúchas. Porto Alegre: Edições IGTF, $1983 \mathrm{~b}$.

PEIRANO, M. Etnografia não é método. Horizontes Antropológicos, ano 20, n. 42: p. 377-391, Porto Alegre: UFRGS, 2014.

PEREIRA, F. M.; LEMOS, M. B. Cidades Médias Brasileiras: Características e Dinâmicas Urbano-Industriais. Pesquisa e Planejamento Econômico, v. 23, n. 1, p. 127-165, 2003.

POTTEIGER, M.; PURINTON, J. Landscape narratives: design practices for telling stories. United States of America and Canada: John Wiley \& Sons, 1998.

QUEIROZ, M. I. P. O messianismo no Brasil e no mundo. São Paulo: Dominus, 1977.

RIBEIRO, C. A paisagem e a ruralidade nos distritos de Vila Seca e Criúva: Caxias do Sul, RS, Brasil. 2014. Dissertação. Faculdade de Ciências Econômicas. Programa de Pós-Graduação em Desenvolvimento Rural, Universidade Federal do Rio Grande do Sul, Porto Alegre.

RIBEIRO, C.; DAL FORNO, M. A. R.; MIGUEL, L. A. A paisagem na ruralidade brasileira: considerações teórico-metodológicas para uma pesquisa multidisciplinar aplicada. Confins [Online], v. 23, p. 1-18, 2015. Disponível em: < http://confins.revues.org/9998 >. Acesso em: 20 março 2015.

ROCHA, A. L. C.; ECKERT, C. Imagens do tempo nos meandros da memória: por uma etnografia da duração. Iluminuras, v. 1, n. 1: p: 1-14, Porto Alegre: UFRGS, 2000.

. Etnografia da Duração. Porto Alegre: Marcavisual, 2013.

SARTORI, J. I. Lei Complementar $n^{\circ}$ 246, de 06 de dezembro de 2005. Caxias do Sul, 2005. Disponível em:

http://www.camaracaxias.rs.gov.br:81/Controldoc.nsf/0/a50a2299e472a1df032570ea006e00f3? OpenDocument >. Acesso em: 08 jan. 2013.

SIMMEL, G. Sociologie et Epistémologie. Paris: PUF, 1981.

SPIVAK, G. Can the subaltern speak? In: WILLIAMS, P. e CHRISMAN, L. (Org.). Colonial Discourse and Post-Colonial Theory: A Reader. Hemel Hemsptead: Harvester Wheatsheaf, 1993.

TEIXEIRA, L. Muito mais que senhores e escravos. Relações de trabalho, conflitos e mobilidade social em um distrito agropecuário do sul do Império do Brasil (São Francisco de Paula de Cima da Serra, RS, 1850-1871). 2008. Dissertação. Centro de Filosofia e Ciências 
Humanas. Programa de Pós-Graduação em História, Universidade Federal de Santa Catarina, Universidade Federal de Santa Catarina.

WALSH, C. ¿Son posibles unas ciencias sociales/culturales otras? Reflexiones en torno a las epistemologías decoloniales. NÓMADAS: Universidad Central-Colombia, p.102-113, 2007.

WANDERLEY, M. N. B. A ruralidade no Brasil moderno. Por un pacto social pelo desenvolvimento rural. In: GIARRACCA, N. (Org.). ¿Una nueva ruralidad en América Latina?. Buenos Aires: CLACSO, Consejo Latinoamericano de Ciencias Sociales, 2001.

WOORTMANN, K. "Com parente não se neguceia". O Campesinato Como Ordem Moral. Anuário Antropológico/87. Brasília: Editora Tempo Brasileiro/UNB, 1990.

ZALUAR, A. Os Homens de Deus. Um estudo dos santos e das festas no catolicismo popular. Rio de Janeiro: Zahar Editores, 1983.

Recebido em: 02/11/2015.

Aprovado em: 15/12/2015. 